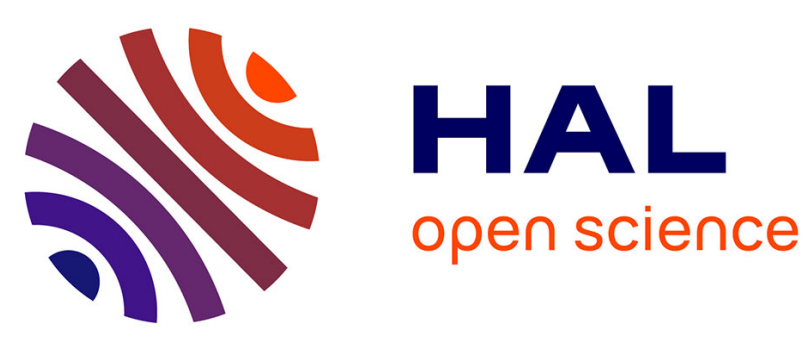

\title{
The northern Caribbean plate boundary in the Jamaica Passage: structure and seismic stratigraphy
}

Jordane Corbeau, Frédérique Rolandone, Sylvie Leroy, Bernard Mercier de Lépinay, Bertrand Meyer, Nadine Ellouz-Zimmermann, Roberte Momplaisir

\section{- To cite this version:}

Jordane Corbeau, Frédérique Rolandone, Sylvie Leroy, Bernard Mercier de Lépinay, Bertrand Meyer, et al.. The northern Caribbean plate boundary in the Jamaica Passage: structure and seismic stratigraphy. Tectonophysics, 2016, 675, pp.209-226. 10.1016/j.tecto.2016.03.022 . hal-01302905

\section{HAL Id: hal-01302905 \\ https://hal.science/hal-01302905}

Submitted on 15 Apr 2016

HAL is a multi-disciplinary open access archive for the deposit and dissemination of scientific research documents, whether they are published or not. The documents may come from teaching and research institutions in France or abroad, or from public or private research centers.
L'archive ouverte pluridisciplinaire HAL, est destinée au dépôt et à la diffusion de documents scientifiques de niveau recherche, publiés ou non, émanant des établissements d'enseignement et de recherche français ou étrangers, des laboratoires publics ou privés. 
The northern Caribbean plate boundary in the Jamaica Passage: structure and seismic stratigraphy

Corbeau J. ${ }^{1}$, Rolandone F. ${ }^{1}$, Leroy S. ${ }^{1}$, Mercier de Lépinay B. ${ }^{2}$, Meyer B. ${ }^{1}$, Ellouz-Zimmermann N. ${ }^{3}$ and Momplaisir R. ${ }^{4}$

1 Sorbonne Universités, UPMC Univ Paris 06, CNRS, Institut des Sciences de la Terre de Paris (iSTeP), 4 place Jussieu 75005 Paris, France

2

Géoazur, CNRS, Univ. Sophia-Antipolis, Valbonne, France

3

IFPEnergies Nouvelles, Rueil-Malmaison, France

4

Université d'Etat d'Haiti, Port au Prince, Haiti

Corresponding author: Jordane Corbeau, jordane.corbeau@upmc.fr 


\section{1. Introduction}

The deadly Mw 7.0 Haiti earthquake of 2010 reminded us of the necessity to characterize the

3 structures and improve understanding of the tectonic processes acting along the northern Caribbean

4 plate boundary. This plate boundary extends from Central America to Puerto Rico and is defined

5 mainly by offshore strike-slip faults, including the Swan Fault, the Septentrional-Oriente Fault Zone

6 (SOFZ), the Walton Fault and the Enriquillo-Plantain-Garden Fault Zone (EPGFZ; Fig. 1). Although

7 previous seismic reflection data acquisition has led to a description of the seismic stratigraphy of the

8 eastern Cayman Trough and the northeastern Lower Nicaraguan Rise (Fig. 1; Leroy et al., 1996;

9 Mauffret and Leroy, 1997; Mauffret and Leroy, 1999), our knowledge of the tectonics remains sparse

10 along several segments of the Northern Caribbean plate boundary. For example, our knowledge of the

11 Jamaica Passage between Jamaica and Hispaniola, which is crossed by the EPGFZ, was formerly based

12 on widely-spaced and low resolution seismic reflection profiles and bathymetry (Robinson and

13 Cambray, 1971; Horsfield and Robinson, 1974; Case and Holcombe, 1980; Mann et al., 1995). During

14 November-December 2012, a marine geophysical survey (HAITI-SIS) was carried out aboard the

15 Research Vessel L'Atalante around the northern Caribbean plate boundary to unravel the detailed

16 geometry of the active fault system (Leroy et al., 2015).

17 Our study focuses on the Jamaica Passage, with the aim of deciphering and characterizing its

18 structure and stratigraphy (Fig. 1). We use high-resolution multibeam bathymetry and 60 multi-channel

19 seismic reflection profiles to image the EPGFZ and the crustal domains between Jamaica and

20 Hispaniola. The bathymetric map highlights the recent fault trace of the EPGFZ as well as distinct

21 morphological features. The seismic reflection profiles acquired during the HAITI-SIS cruise are

22 compared with former reflection seismic studies in the Caribbean area in order to define the main

23 stratigraphic sequences in the Jamaica Passage. Based on morphological, structural and

24 sedimentological criteria derived from the combined interpretation of the bathymetry and seismic data, 
25 we identify two distinct crustal domains and two distinct basin structures in the vicinity of the

26 EPGFZ. The new HAITI-SIS data set is then used to propose a structural sketch of the Jamaica Passage 27 and highlights its main tectonic features.

29 2. Geological setting

The Caribbean plate's interior is mainly formed by a Cretaceous Oceanic Plateau, known as the

31 Caribbean Large Igneous Province (CLIP). This province is covered by extended lava flows of varying

32 thickness that cover an igneous basement. Seismic stratigraphy studies of the Caribbean crust have

33 described several seismic units typical of oceanic material in the Colombian Basin (Lu and McMillen,

34 1982; Bowland, 1993) and in the Venezuelan Basin (Ladd and Watkins, 1980; Ladd et al., 1990;

35 Diebold et al., 1999; Driscoll and Diebold, 1999) with thickness of the crust around $5 \mathrm{~km}$. Moreover,

36 the interpretation of seismic reflection data has led to identification of the Carib Beds (Caribbean

37 typical prominent reflection horizons $\mathrm{A}^{\prime \prime}$ and $\mathrm{B} "$ ), which have been drilled and widely mapped in the

38 Venezuelan Basin (Fig. 1; Ladd and Watkins, 1980; Diebold et al. 1981; Diebold et al., 1999; Driscoll

39 and Diebold, 1999; Granja Bruña et al., 2009; Kroehler et al., 2011), in the southwest and west of the

40 Colombian Basin (Fig. 1; Bowland, 1993; Bowland and Rosencrantz, 1988), south of the Beata Ridge

41 (Fig. 1; Hopkins, 1973; Stoffa et al., 1981) and in the Lower Nicaraguan Rise (Fig. 1; Mauffret and 42 Leroy, 1997).

The CLIP was formed during the Cretaceous on the Pacific Farallon plate, over the Galapagos 44 hotspot (Duncan and Hargraves, 1984), while the Greater Antilles volcanic arc (i.e., Cuba, Hispaniola 45 and Puerto Rico) was initiated by an eastward dipping subduction in Central America (Pindell, 2012; 46 Van der Lelij, 2013; Hastie et al., 2013). The volcanic arc and the plateau subsequently moved north47 and eastwards to their current position between the North and South American plates, thus 48 individualizing the current Caribbean plate. The eastern Greater Antilles arc (i.e., Hispaniola and Puerto 
49 Rico) became an inactive intra-oceanic arc during the northeastward motion of the Caribbean plate. The

50 northeastward motion of the newly formed Caribbean plate lasted until the beginning of the collision

51 between the western Cuban arc and the Bahamas carbonate platform in the Paleocene (Leroy et al.,

52 2000, Cruz-Orosa et al., 2012).

53 The progressive collision between the Cuban arc and the Bahamas platform led to the

54 localization of a left-lateral fault zone south of Cuba, followed by the opening of the Cayman Trough

55 system during the Eocene (Fig. 1; Mann, 1997; Leroy et al. 2000; Pubellier et al., 2000). The Cayman

56 Trough (CT in Fig. 1) is a narrow oceanic trough created on either side of a short spreading centre

57 (MCSC, Mid-Cayman Spreading Centre) separating the conjugate passive margins of Belize in the

58 West and North Jamaica in the East, as a response to the northeastward motion of the Caribbean plate

59 relative to the North American plate (Holcombe et al., 1973; Goreau, 1981; Rosencrantz and Sclater,

60 1986; Rosencrantz et al., 1988; Leroy et al., 1996).

61 Studies including multichannel seismic acquisition (Sykes et al., 1982; Leroy et al., 1996) and

62 swath mapping (Rosencrantz and Mann, 1991; Leroy et al., 1996) in the eastern Cayman Trough, as

63 well as field mapping in Jamaica (Burke et al., 1980; Abbott et al., 2013, James-Williamson et al.,

64 2014) were carried out to understand the opening of the Cayman Trough system since the early Eocene

65 and the formation of the North Jamaica passive margin. Leroy et al. (1996) interpreted the basement of

66 the eastern Cayman Trough, between Cuba and Jamaica, as a Mesozoic continental crust rifted in a

67 succession of parallel tilted blocks trending northeast-southwest (Fig. 2). These blocks form a series of

68 sedimentary basins initiated and infilled during the rifting phase. The onset of oceanic spreading at the

69 toe of the margin (Fig. 2) is dated at about 49 Ma by the record of magnetic anomaly 22 (Ypresian,

70 early Eocene; Leroy et al., 2000; Hayman et al., 2011) in agreement with onshore studies, contrary to

71 Rosencrantz et al. (1988) dating the opening at anomaly 20 ( 40 Ma). At a first-order level, the

72 transition from rifting to oceanic spreading corresponds to an unconformity separating the tilted syn-rift 
73 seismic sequences from the post-rift layers on the proximal margin domain. Unfortunately, there are no

74 drill-holes to constrain the age of the sediments infilling the basins. However, owing to the exposure of

75 such a basin subsequently inverted as a restraining bend in Jamaica, the ages of the syn-rift seismic

76 sequence can be estimated by comparison with their onshore equivalents. The Wagwater inverted

77 graben (Fig. 2) is filled by syn-rift Paleocene and early Eocene sediments (Richmond and Wagwater

78 formations; Mann, 1985; Mann and Burke, 1990), representing the equivalent of the extensional regime

79 of the eastern passive margin of the Cayman Trough system during the rifting time. The associated

80 normal faults of the Blue Mountains (BM; Fig. 2) were then sealed by an accumulation of carbonate

81 formations (Yellow Limestone and White Limestone) associated with post-rift platforms, from the

82 middle Eocene to the middle Miocene (Wadge and Dixon, 1984). This time-span of rifting fits well

83 with that observed on the eastern Cayman Trough margin (Leroy et al., 1996; 2000). southeastern Cuba and on Hispaniola (Bowin, 1975; Calais and Mercier de Lépinay, 1995; Dillon et al., 1992). This unconformity relates to a paleogeographic rearrangement, induced by the obliquity of the convergence between Cuba and Hispaniola to the south and the Bahamas to the North (Pindell and 88 Barrett, 1990; Mann et al., 1995). At the same time, Cuba and Hispaniola begin to be separated along 89 the SOFZ (Fig. 1; Pindell and Barrett, 1990). Moreover, during the Miocene, the CLIP collides with the 90 southwest of Hispaniola (Calmus, 1983; Pindell and Barrett, 1990; Granja Bruña et al., 2014) and a 91 compressive deformation begins to develop in Hispaniola (Haitian fold-and-thrust belt, Pubellier et al., 92 2000). The pre-existing structures of Jamaica are overprinted by left-lateral transcurrent tectonics from 93 the middle Miocene onwards (Mann et al., 1985; Lewis and Draper, 1990; James-Williamson et al., 94 2014). This transcurrent tectonic style is due to the propagation of the southeastern edge of the Cayman 95 Trough along the offshore Walton fault west of Jamaica and along the EPGFZ in Jamaica, extending to 96 onland Hispaniola as well as into the Jamaica Passage between Jamaica and Hispaniola (Fig. 2; Mann 
et al., 1995; Leroy et al., 2000).

Currently, the eastward motion of the Caribbean plate is still accommodated along the major transform faults that extend from Central America to Puerto Rico, including the Swan Fault, the SOFZ,

100 the Walton Fault and the EPGFZ (Fig. 1; Mann et al., 2002). The SOFZ to the north and the

101 Walton/EPGFZ to the south are the limits of a crustal block named the Gonâve microplate (Fig. 1;

102 Rosencrantz and Mann, 1991).

103

104

105

106

107

108

109

110

111

112

113

114

115

116

117 A". The third seismic unit corresponds to lithified chalks, cherts, limestones and black shales. The base

118 of this unit is composed of Santonian to Coniacian basalts named as horizon B". Underneath the third

119 seismic unit, horizons denoted as V, or "Upper volcanic sequence", correspond to volcanic sills

120 (Diebold et al., 1999). Near the Jamaica Passage, the CLIP was identified in Hispaniola and Jamaica 
121 thanks to outcrops (Hastie et al., 2008), in the Lower Nicaraguan Rise thanks to reflection seismic

122 profiles and DSDP and ODP drills (Edgar et al., 1973; Mauffret and Leroy, 1997), and in the Beata

123 Ridge thanks to diving (Mauffret et al., 2001) (Figs. 1 and 3). The extent of the identified CLIP is 124 shown in green in Fig. 3.

125 The structure of the continental passive margin of the eastern Cayman Trough between Cuba 126 and Jamaica was identified by a multichannel seismic survey (Leroy et al., 1996; Fig. 3). The major 127 normal faults bound 10-20 km wide half-grabens displaying escarpments ranging from a few hundred 128 of meters to more than $3000 \mathrm{~m}$ (about $2 \mathrm{~s}$ two-way travel time, hereafter referred as twtt). In the NE129 SW trending basins, the syn-rift layers are up to $0.2 \mathrm{~s}$ twtt thick ( $\sim 200 \mathrm{~m}$ with a velocity in the syn-rift 130 sediments of $2000 \mathrm{~m} / \mathrm{s})$ and the post-rift layers are up to $1.2 \mathrm{~s}$ twtt thick $(\sim 1000 \mathrm{~m}$ with a velocity of $1311700 \mathrm{~m} / \mathrm{s}$ ). Seismic interpretations based on comparisons with onshore formations in Jamaica identified 132 three main seismic units (Fig. 3a). A lower seismic unit corresponds to faulted and tilted blocks, with 133 internal smooth reflectors consisting of Upper Cretaceous pre-rift sediments. The second seismic unit 134 corresponds to Paleocene to Early Eocene fan-shaped sedimentary bodies, associated with the syn-rift 135 sequence. The upper seismic unit is made up of strong parallel reflectors corresponding to Middle 136 Eocene to Recent deposits related to the post-rift sequence. The extent of the eastern Cayman Trough 137 passive margin identified by Leroy et al. (1996) is shown in blue in Fig. 3. 3.2 Seismic reflection study in the Jamaica Passage

Using four multichannel seismic profiles acquired in 1980 by University of Texas-Institute for

141 Geophysics aboard the R/V Fred Moore, Mann et al. (1995) mapped the EPGFZ trace and the main 142 morphological features of the Jamaica Passage (Fig. 4). They imaged a narrow 3-7- km-wide fault 143 trough (the Navassa Basin in this study, Fig. 5) and marked escarpments they used to locate the 144 EPGFZ. They also interpreted the central fault trough as a pull-apart basin cut by faults along both its 
145 northern and southern edges. However, the resolution of the seismic reflection lines did not allow them

146 to detail the stratigraphy of the area and to identify the nature of the crustal domains.

\section{4. Data collection}

This study makes use of high-resolution multibeam bathymetry and multi-channel seismic

150 reflection data collected during the 2012 HAITI-SIS cruise off Haiti on the R/V l'Atalante. The seismic

151 data acquisition was carried out by a 24-channel high-resolution system operated at approximately 9.7

152 knots (rapid seismic system), with a source composed of two GI guns (shot interval of $10 \mathrm{~s}$ ) of $2.46 \mathrm{~L}$

153 (150 in3). Processing of the multichannel seismic reflection data used classical steps including CDP

154 gathering (6-fold), binning at $25 \mathrm{~m}$, velocity analysis, stack and post-stack time migration. The

155 maximum penetration is 1.5 to $2 \mathrm{~s}$ twtt. All the profiles presented here are time migrated and with a

156 vertical exaggeration of 5. High-resolution swath bathymetry data was acquired with a maximum

157 precision of $25 \mathrm{~m}$ using a hull-mounted multibeam echosounder system. The overall geometry of the

158 active offshore fault system, including a full coverage bathymetric map, and one seismic profile

159 collected are presented in Leroy et al. (2015). In this study, we focus on the Jamaica Passage and the 160 interpretation of 60 seismic reflection profiles sampling the EPGFZ between Jamaica and Hispaniola 161 (Fig. 5), including 9 key profiles that are shown here.

\section{5. Stratigraphy and structure of the Jamaica Passage}

\subsection{Bathymetry}

165

Fig. 6 presents a bathymetric map of the Jamaica Passage between Jamaica and Haiti. This

166 bathymetric map highlights the most recent fault trace of the EPGFZ disrupting the seafloor, and 167 crossing several distinctive morphological features from west to east: three basins with an average 
168

169

170

171

172

173

174

175

176

178

179

180

181

182

183 184 (2012).

185

186

187

188

189

190

191

depth of $2500 \mathrm{~m}$ (the Morant, Navassa and Matley basins), three topographic highs north of the EPGFZ

with an average depth of $500 \mathrm{~m}$ (the Holmes Bank, the Formigas Bank and the Navassa Ridge topped by Navassa Island) and three other topographic highs south of the EPGFZ with an average depth of 800 m (the Morant Ridge, the Albatros Bank and the Matley Ridge; Fig. 6).

\subsection{Seismic reflection profiles}

Our main purpose is to define the main stratigraphic sequences in the Jamaica Passage and characterize its tectonic feature, using the new collected data set. The definition of the seismic units and the stratigraphic correlation have been established with numerous seismic reflection profiles (see the coverage on Fig. 5) and not only with the six profiles shown in this paper. The correlative surfaces of the unit boundaries correspond to strong reflections, unconformities and distinctive patterns that we were able to correlate throughout the grids of seismic reflection data. Because of the slope drapes at basin flanks and topographic highs, and the distribution of the seismic profiles, correlation of seismic horizons from one basin to another cannot be done with the standard "loop-tying" method for 2D seismic reflection data (Herron and Latimer, 2011). However the characteristics of the seismic horizons are sufficient to allow "jump" correlation of marker beds between basins as done by Prather et al.

Based on morphological, structural and sedimentological criteria derived from the combined interpretation of the bathymetry and seismic data, we identify distinct crustal domains in the Jamaica Passage. The Fig. 5 shows the complete coverage of seismic profiles collected and interpreted here and highlights the profiles used to illustrate our key observations.

\subsubsection{Acoustic basement}

The top of the acoustic basement is defined as the most continuous and distinct high-amplitude 
192 horizon underlying the deepest sediments. This horizon is well marked by a distinct high-amplitude

193 reflection (Fig. 7). The top of the acoustic basement underlying sediments, identified in the majority of

194 the seismic profiles in the Jamaica Passage, is continuous. Beneath the top of the acoustic basement,

195 the seismic basement (hereafter SB) shows two different facies related to its topography. At the base of

196 the basins, the SB presents tilted parallel reflections (enlarged views 1 and 4, Fig. 7). Outside the

197 basins, on topographic highs and ridges, the SB is more disrupted and chaotic, with local coherent

198 parallel reflections (enlarged views 2 and 3, Fig. 7). That chaotic basement is not systematically

199 observed below ridges with rugged sea-floor discards the possibility of velocity pull-up and pull-down

200 artifacts. The inset map in Fig. 7 shows the continuous SB unit in the Jamaica Passage and the

201 repartition of its two distinct facies.

202 The depth to basement map of the unit SB (i.e., sea level-top of SB unit interval), derived from

203 all the seismic profiles reveals the presence of several basins in the Jamaica Passage (Fig. 8). The three

204 deeper basins, well visible in the bathymetry (Fig. 6), have a top of the SB unit reaching in average

2054.000 m-deep for the Morant and Matley Basins, and 3.200 m-deep for the Navassa Basin (Fig. 8).

206 Three shallower basins, not easily visible in the bathymetric map, are identified with a top of the SB

207 unit reaching in average 2.800 m-deep (Fig. 8).

208

209

\subsubsection{Basin structures}

210

211 depth to basement map along the seismic reflection profiles (Fig. 8). The westernmost basin, just at the

212 toe of the southeastern tip of Jamaica, is the Albatros basin. This basin is bounded to the south by a

213 strong escarpment of $\sim 700 \mathrm{~m}$ (CMP \#1800, Fig. 9a). Within the basin, we distinguish five seismic units

214 (SB, U1, U2, U3 and U4) corresponding to the main phases of basin infilling. The seismic basement

215 (SB unit, Fig. 9a) is clearly imaged beneath the basin around CMP \#1500. This unit dips toward the 
216 south in the direction of the escarpment. A fan-shaped unit, denoted as U1 unit, overlies the SB unit,

217 reaching a maximum thickness of about $0.5 \mathrm{~s}$ twtt. The onlap reflectors at the transition between SB

218 and U1 exemplify that U1 lies unconformably on SB unit (Fig. 9a, CMP \#1400). Above the U1 unit,

219 the U2 unit infills the basin and lies conformably over U1. The U2 unit reaches a maximum thickness

220 of about $0.35 \mathrm{~s}$ twtt and shows several parallel reflectors. The transition between U2 and the overlying

221 U3 unit is marked by a strong reflection and a few onlaps. Another reflection, at the base of a facies

222 with wider spacing between reflectors, defines the boundary between the U3 and U4 units. This

223 transition is also marked by the onlap of the U4 unit reflections above the U3 unit (Fig. 9a). All the

224 seismic units SB, U1, U2, U3 and U4 are deformed and folded. The units are uplifted on their southern

225 side and are thus tilted toward the centre of the basin. Nevertheless, the escarpment, the tilted SB unit

226 and the fan-shaped U1 unit, all indicate that the Albatros Basin could be a half-graben and the

227 escarpment a former normal fault. Then the bathymetric escarpment could be the exposed fault scarp.

228 Thus, SB corresponds to the pre-rift basement, the fan-shaped U1 unit may be interpreted as a syn-rift

229 sequence with sediment thickness increasing toward the escarpment, while U2, U3 and U4 are isopach

230 and could be interpreted as no normal fault-related sequences called post-rift. The deformation and the

231 tilt of the units could indicate an inverse reactivation of the former normal fault. Fig. 9b shows a sketch

232 illustrating how such a basin can be formed in scale 1:1. Step 1 shows the normal fault-related deposit

233 of the U1 unit in an half-graben, called syn-rift. Step 2 is the time deposition of the flat unit U2 called

234 the post-rift unit. Step 3 is the time deposition of the unit U3 in unconformity on the U2 unit than

235 begins to be folded. The formation of onlaps at the transition U2/U3 (Fig. 9a) indicates that a context of

236 compression began at this time during the U3 deposit. Step 4 shows the present-day configuration, and

237 the deposition of the unit U4 in unconformity on the older folded units, during a second compressive

238 episode. The half-graben is afterward inverted in a compressive context, and the former normal fault

239 created by the first extensive phase may have been reactivated as a reverse fault during the compressive 
phases.

In the northeast of Albatros basin and west of the Jamaica Passage, the 4600 m-deep Morant

242 basin is cross-cut by the EPGFZ. Fig. 10 provides details of seismic profile H12-036 (see Fig. 5 for

243 location) showing that the Morant basin is also bounded to the south by a marked escarpment of $\sim 1000$

$244 \mathrm{~m}$ (CMP \#1700, Fig. 10). This basin is deformed between CMP \#1550 and \#1200 and that gives a

245 transparent facies at depth. Fig. 11 presents enlarged excerpts of the profile pointing out the

246 unconformities between the different seismic sequences. Five seismic units can be distinguished in the

247 northern part of the profile (Fig. 10 and enlargement Fig. 11a). These units have the same

248 characteristics than those identified and described in the Albatros Basin (Fig. 9), and are thus named

249 with the same nomenclature: the SB unit is tilted toward the southern escarpment; the U1 unit is fan-

250 shaped with a thickness increasing toward the escarpment; the U2 unit shows several parallel

251 reflections; the transition between the U2 and U3 units is marked by a strong reflection and onlaps and

252 the U4 unit onlaps the U3 unit. However, as the Morant Basin is cut by the strike-slip EPGFZ (CMP

253 \#1500 in Fig. 10 and Fig. 6), seismic units with different thicknesses could have been juxtaposed on

254 either side of the fault by post-depositional motion, preventing to follow the U1, U2 and U3 units on

255 both sides of the fault. Nonetheless, by comparing their characteristics the Morant Basin could 256 originated as a half-graben similarly to the Albatros Basin. Enlargement of the U4 and U3 units located 257 near the EPGFZ trace and presented in Fig. 11B shows the thickness variation of the unit U4 around the 258 EPGFZ, which onlaps on the U3 unit. The unit U4 is thicker in the strike-slip furrow of the EPGFZ 259 (CMP \#1500), which indicates that the upper U4 unit was deposited during the activity of the EPGFZ. The Matley Basin, east of the Jamaica Passage, displays similar characteristics (Fig. 12). This

261 basin is also bounded by a prominent escarpment along its southeastern boundary. The interpretation of

262 the seismic sequences shows same seismic units similar to there already identified in the Albatros Basin 263 (Fig. 9) and in the Morant Basin (Fig. 10). Unlike the Morant Basin, the Matley Basin is cut by the 
264 EPGFZ on its northwestern border (Figs. 6 and 12). Between CMP \#800 and \#1000, the sediments are 265 deformed and folded, resulting in transparent facies in depth around CMP \#800. Close to the 266 escarpment, the sediments (around CMP \#600) dip toward the NW, away from the escarpment. The 267 sediments are tilted towards the centre of the basin indicating that the southeastern border of the basin 268 has been uplifted. Sediments of the Matley half-graben show compressive deformation in the same way 269 than in the Albatros and Morant half-grabens. In the Matley Basin, the infilling has a total thickness of 270 about $1 \mathrm{~s}$ twtt near the CMP \#600 (Fig. 12), apparently greater than along the profile of the Morant 271 Basin. The profile crossing the Morant Basin is indeed shifted eastward with respect to the basin 272 depocentre.

Between the Morant and Matley basins, the Navassa Basin exhibits distinct features compared 274 to the Albatros, Morant and Matley half-grabens, both regarding its shape in map-view (narrower and 275 more elongated) and its infilling (about three times less thickness of sediment). Figs. 13a and 13b show 276 details of the H12-032 and H12-052 seismic profiles crossing the Navassa Basin. The sediment 277 thickness in this basin is restricted to $0.3 \mathrm{~s}$ twtt on average, and the reflectors are strong, parallel and 278 flat, without marked differences within the seismic sequence. The seismic profiles in the Navassa Basin 279 show that the oldest units (U1, U2 and U3) of the Albatros, Morant and Matley basins are missing (Fig. 280 13). Thus the only seismic sequence identified is the more recent U4 unit, which directly overlies the 281 seismic basement (SB unit). The thickness of U4, as presented in Fig. 13, may appear greater in the 282 Navassa basin, but the thickness of U4 varies in the all basins as exemplified in the Morant basin (Fig. 283 10). Moreover, unlike the Morant and Matley basins that are obliquely crossed by the present-day trace 284 of the left-lateral EPGFZ (Figs. 6, 10 and 12), the northern limit of the Navassa basin follows the trace 285 of the fault (Figs. 6 and 13). Around CMP \#12500 on Figs. 13a and 13b, the sediments of the U4 unit 286 are slightly folded, as observed in the other basins. The seismic profiles indicate that we can not 287 observe strike-slip fault segment in the south of the basin. The enlarged view of the bathymetric map, 
shown in Fig. 13c, highlights the straight and continuous EPGFZ on the northern side of the Navassa

289 Basin, and its sinuous non-faulted southern border.

The identification of the units in the different basins was based on the characteristics of the

291 seismic horizons and on the unit boundaries corresponding to strong reflections, unconformities and

292 distinctive patterns. As we already emphasized, slopes and topography highs prevented us to apply the 293 standard "loop-tying" method to correlate our units. However, we carried out a "jump" correlation of 294 marker beds between basins. Fig. 14 presents a synthesis of the seismic stratigraphic correlation of the 295 different seismic units between the Albatros, the Morant, the Navassa and the Matley basins.

\subsubsection{A distinct crustal domain}

At some distance from the basins, the seismic profiles yield a very different image of the

sedimentary reflections (Figs.. 15 and 16). On these profiles, the reflections are chaotic or parallel and sub-horizontal, and always typified by strong reflections. Fig. 15 shows the seismic profile H12-053,

301 situated in the south of the study area. The seismic interpretation of this profile highlights several 302 seismic sequences: 1) an upper sequence, made up of strong and thick reflectors. The reflectors are 303 parallel and overlie deformed seismic reflections resulting in a non-planar seafloor. This upper unit has 304 a thickness of about $0.2 \mathrm{~s}$ twtt; 2) a second seismic sequence, about $0.5 \mathrm{~s}$ twtt thick, consisting of 305 interbedded thin and strong reflectors. The reflectors are parallel in the lower part of the unit and more 306 chaotic in the upper part; 3) a third sequence, consisting of strong parallel reflections in the upper part, 307 with two pronounced reflectors, and a transparent facies in the lower part; 4) a lower sequence 308 corresponding to a chaotic seismic sequence, including several strong and short curved reflectors. The 309 second and third units are deformed and faulted.

310 Fig. 16 shows the seismic profile H12-022, situated at the extreme southeast of the study area.

311 On this profile, the same seismic reflections are identified, and thus the same distinct seismic sequences 
312 may be defined. However, this seismic profile does not show deformation and faults affecting the

313 seismic sequences.

314 One possible interpretation of this crustal domain, markedly different from the basin structures,

315 is to relate it to the CLIP, identified, in the vicinity of our study area, on reflection seismic profiles,

316 DSDP and ODP drills, and diving as described in Section 3.1 and shown in Fig. 3. However, because

317 the seismic profiles in Fig. 3 are several hundreds of km apart from our profiles displayed in Figs. 15

318 and 16, we could only put forward the hypothesis that the crustal domain we image is possibly the

319 CLIP as discussed in Section 6.4.

\section{Discussion}

\subsection{Stratigraphy and origin of the half-grabens}

In the Jamaica Passage area, no drills are available. It is thus difficult to correlate our seismic

324 reflection units to known ages, and to propose a detailed stratigraphy of the area to explain the

325 formation and the origin of the identified half-graben basins. One hypothesis may be that Morant and

326 Matley basins, well expressed in the bathymetry and cross-cut by the EPGFZ, have been created by the

327 fault during its strike-slip motion. However, the interpretation of the new seismic reflection dataset

328 allows us to identify three other half-graben basins outside of the EPGFZ trace (the Albatros Basin

329 south of the EPGFZ and two others basins north of the EPGFZ, Fig. 8). The Albatros Basin (Fig. 9)

330 exemplifies a typical half-graben basin. These basins have the same seismic units than those of the

331 Morant and Matley basins. All the identified basins are half-grabens with a fan-shaped seismic unit

332 (U1) typical for a syn-rift deposition, and a normal fault escarpment on their south/southeastern side 333 which trend about NE-SW (Fig. 17). These basins also show the same seismic units U2, U3 and U4

334 than those of the Morant and Matley basins. The presence of similar half-graben basins outside the 335 trace of the EPGFZ does not support the hypothesis that the Morant and Matley basins were created by 
the EPGFZ activity. Another hypothesis could be to interpret these half-graben basins in relation with a

337 previous extensional period, independent from the EPGFZ activity. The sedimentary and tectonic 338 characteristics of the five half-grabens identified in the Jamaica Passage could be related to the 339 characteristics of the half-graben basins encountered north of Jamaica and described in Leroy et al. 340 (1996) as shown in Fig. 3a. By comparison, the Albatros, Morant and Matley basins sedimentary filling 341 is thicker than that found between Cuba and Jamaica ( $1 \mathrm{~s}$ twtt versus $0.7 \mathrm{~s}$ twtt), which may be 342 explained by the proximity of the sediment sources of Jamaica and Haiti. They also seem to be more 343 deformed than those identified in the North Jamaica area. The resolution of the seismic reflection 344 profiles and the acquisition methods are not the same between the two studies, making difficult to 345 compare in detail the stratigraphy. Moreover, the Jamaica Passage is situated on the transpressive 346 boundary between the Gonâve microplate and the Caribbean plate (Rosencrantz and Mann, 1991, 347 Mann et al., 1995), unlike the North Jamaica area which is on the Gonâve microplate interior, 348 providing an explanation for the greater deformation observed in the Jamaica Passage. Another 349 argument is provided onland in Jamaica by the Wagwater restraining bend, also interpreted to be an 350 inverted half-graben coeval with the Cayman Trough margin rifting episode (Mann et al., 1985; Mann 351 and Bruke, 1990). We thus favor the hypothesis that the five half-grabens identified in the Jamaica 352 Passage are coeval with the rifting episode that formed the passive margin of Jamaica from the early 353 Paleocene to the early Eocene (Mann and Burke, 1990). Using the geological field studies carried out in Jamaica and Hispaniola (e.g. Mann and Burke, 355 1990) and the marine geophysical surveys in the area (Dillon et al., 1992; Calais and Mercier de 356 Lépinay, 1995; Leroy et al., 1996, 2000), we tentatively correlate the seismic units identified in the 357 half-grabens of the Jamaica Passage with the known regional tectonic unconformities. The SB unit 358 could correspond to the Mesozoic continental crust making up the pre-rift formations of the passive 359 margin. The U1 syn-rift sequence could be correlated with the Paleocene and early Eocene sediments 
360 of the onshore Wagwater graben in Jamaica (Mann et al., 1985). Moreover, the magnetic anomalies of

361 the Cayman Trough oceanic crust indicate that the unconformity between the rifting episode (syn-rift

362 deposits) and the spreading episode (post-rift deposits) represents an interval during the Ypresian ( 49

363 Ma, Leroy et al., 2000). This leads us to propose an age of 49 Ma for the transition between the U1

364 syn-rift and U2 post-rift sequences. Following Wadge and Dixon (1984), the U2 post-rift sequence may

365 correspond to the carbonate platforms (Yellow Limestone and White Limestone) identified on Jamaica.

366

\subsection{Evidence for a first shortening phase}

368

We already underlined that the half-grabens are deformed and folded. The seismic reflection

profiles acquired across the Jamaica Passage provide a more detailed image of the post-rift sequence

(Figs. 9, 10, 11, 12), the unit U2 is deformed indicating a phase of tectonic shortening recorded in the

372 three basins. Specifically, the unconformity between the U2 and U3 post-rift sequences could

373 correspond to the regional tectonic rearrangement recorded in the early Miocene (about 20 Ma, Calais

374 and Mercier de Lépinay, 1995; Pindell and Barrett, 1990), coeval with a southward jump of the

375 Cayman Trough spreading centre (Leroy et al., 2000). This rearrangement led to a prominent

376 sedimentary unconformity cropping out onshore in southeast Cuba and on Hispaniola, as well as

377 offshore in the Windward Passage along the SOFZ (Calais and Mercier de Lépinay, 1995). This

378 prominent unconformity has long been interpreted as the result of folding and uplift of the basement

379 due to the oblique collision with the Bahamas platform (e.g., Pindell and Barrett, 1990).

\subsection{Structure and deformation related to the strike-slip EPGFZ}

The U4 unit is the only sedimentary sequence that we can identify in the Navassa Basin (Figs.

38313 and 14). Mann et al. (1995) interpreted this basin as a pull-apart basin bounded to the north and the 
south by two offset segments of the EPGFZ (Fig. 4). The recent bathymetry data (Fig. 6) indicate that the trace of the EPGFZ can only be followed along the northern edge of the rectangular-shaped Navassa Basin. The seismic profiles (Fig. 13) also clearly indicate that no strike-slip fault segment is present to the south of the basin.

This leads us to interpret it rather as an asymmetrical strike-slip related basin. Such types of asymmetrical basin have been identified along several strike-slip faults, for example, along the North Anatolian Fault in the Marmara Sea (Seeber et al., 2010; Choi et al., 2011) in the vicinity of typical pull-apart basins (Armijo et al., 2002), along the Dead Sea Fault (Ben-Avraham and Zoback, 1992) and along the Polochic Fault in Guatemala (Ben-Avraham, 1992). We thus interpret the unit U4 as a syntectonic sequence deposited during the activity of the EPGFZ. Based on conventional field geology and the identification of local unconformities, the onset of activity of the EPGFZ is estimated to be middle Miocene (Draper, 1987) to late Miocene (14 Ma, James-Williamson et al., 2014) in Jamaica, and early Miocene in Haiti (Calmus, 1983).

The trace of the EPGFZ cuts across the proposed inherited Morant and Matley basins (Figs. 6, 10 and 12). Figs. 10 and $11 \mathrm{~b}$ show that the unit U4 is thicker within the strike-slip furrow of the EPGFZ (CMP \#1600) than at distance away from the fault trace (CMP \#1400). This observation as well indicates that the EPGFZ was active during the deposition of the upper U4 unit. The Morant and Matley half-graben basins are thus further deformed by the activity of the EPGFZ. Similar observation was done by onland field surveys in Jamaica where the activity of the EPGFZ in the middle Miocene overprints the older extensional structures (James-Williamson et al., 2014). In all the proposed inherited half-grabens, even outside the trace of the EPGFZ, like in the Albatros Basin (Figs. 9, 10, 11, 12), the U4 unit is deformed and folded and is unconformable on the older U3 unit. This indicates a phase of shortening across the Jamaica Passage during the activity of the EPGFZ. This shortening witnesses the transpressive tectonics along this plate boundary. The present-day oblique motion 
408 between the Caribbean and North American plates, converging in an ENE-WSW direction at about 20

$409 \mathrm{~mm} / \mathrm{yr}$, is accommodated by several active faults and folds in and around Hispaniola (Mann et al.,

410 1995). The EPGFZ is one of the major structure accommodating $\sim 7 \mathrm{~mm} / \mathrm{yr}$ of pure strike-slip motion

411 (Manaker et al., 2008). However, recent block modeling based on GPS velocities (Calais et al., 2010;

412 Benford et al., 2012b; Symithe et al., 2015) predict along the EPGFZ, a component of fault-normal

413 convergence in addition to the main strike-slip motion. The magnitude of this fault-normal component

414 varies between the models depending on the geometry of the blocks and the data set, but suggests

415 significant transpression on the EPGFZ. In the Jamaica Passage, the primary structures of the EPGFZ

416 are a series of strike-slip fault segments associated to geomorphic features highlighting a primary

417 strike-slip motion (Leroy et al., 2015). Our seismic and structural study of the Jamaica Passage

418 evidences an asymmetrical strike-slip related basin (the Navassa Basin, Fig. 13) that attests as well of

419 the primary strike-slip motion of the EPGFZ.

The block models predict fault-normal and fault-parallel components on block boundaries, the

421 blocks being rigid. Their hypothesis is thus that the deformation (strike-slip and compressive) is 422 entirely localized on the block boundaries, here the EPGFZ. Benford et al. (2012b) nonetheless 423 acknowledge that the fault-normal convergence predicted by their model is partitioned onto the EPGFZ 424 and structures north and possibly south of the fault zone. We evidence some shortening in the Jamaica 425 Passage, not only in the two half-graben Basins crosscut by the EPGFZ, but also in the Albatros Basin, 426 south of the trace of the EPGFZ. However, to constrain the plate motion partitioning of the deformation 427 between fault-normal convergence and strike-slip motion, the structures north of the EPGFZ have to be 428 investigated, and particularly the Gulf of Gonâve, the offshore prolongation of the Haiti fold-and-thrust 429 belt (Mann et al., 1995). 
433 markedly distinct characteristics from the basin structures. The bathymetric map (Fig. 6) also shows

434 that the seafloor appears to be rougher here than in the area where we mapped the Cayman-related 435 inherited basins. In the vicinity of the Jamaica Passage, in the Lower Nicaraguan Rise, in the

436 Colombian Basin and in the Beata Ridge, the CLIP was previously identified thanks to the presence of 437 the Caribbean typical reflectors and confirmed by drilling (DSDP and ODP) and submersible dives

438 (Fig. 3). We propose that the seismic sequences identified in the southeast of the Jamaica Passage and 439 shown in Fig. 15 and 16 could image the CLIP. The four seismic sequences, described in Section 5.2.3, 440 display stmilar characteristics with the reflectors typifying the CLIP as shown in Fig. 3. We put forward 441 the hypothesis that these sequences could correspond to the typical horizons of the CLIP. The upper 442 unit shown in Fig. 15 and 16 could correspond to the uppermost sequence of the CLIP lying upon the 443 eM horizon. The intermediate unit could be correlated with the sequences containing the typical A" and 444 B" reflectors. Finally, the curved reflectors imaged in the lower unit could be correlated with the V 445 horizons of the CLIP as proposed by Mauffret and Leroy (1997).

\subsection{Tectonic implications}

Following our proposed interpretations, the Jamaica Passage consists of two pre-existing crustal 449 domains - the Eastern Cayman Trough passive margin and the CLIP - for which we propose a new 450 structural scheme (Fig. 18). The Albatros, Morant and Matley basins, identified in the Jamaica Passage, 451 are interpreted as half-grabens of the Eastern Cayman Trough margin. The presence of tilted blocks 452 belonging to the Eastern Cayman Trough passive margin has already been proposed in the eastern part 453 of the Gonâve microplate based on paleotectonic reconstructions and magnetic mapping (Pubellier et $454 a l .$, 2000). The easternmost tilted block of the Eastern Cayman Trough passive margin imaged in 455 previous surveys was the Holmes bank (Fig. 2) near northeast Jamaica (Leroy et al., 1996), but we 
propose here that this continental passive margin extends at least as far as the Matley Basin near the

457 southwestern tip of the Southern Peninsula of Haiti. In the southern part of the Jamaica Passage, the 458 interpretation of the seismic profiles with the typical seismic reflectors (A", B" and V) could indicate 459 that the CLIP is present up to the southern part of the Jamaica Passage, at the extreme northeast of the 460 Lower Nicaraguan Rise.

461 In our interpretations, the EPGFZ does not follow the limit between these two domains 462 displaying distinct crustal rheologies. The EPGFZ cuts obliquely across the rheological boundary and 463 also across the pre-existing half-grabens. As a consequence, tectonic inheritance does not seem to have 464 played a major role in the mechanical processes involved with the localization of the present trace of 465 the EPGFZ. Such an observation is reported along the trace of the very few major strike-slip faults 466 known to have propagated such as the North Anatolian Fault (Armijo et al., 1999) or the Altyn Tagh 467 Fault (Peltzer and Tapponnier, 1988; Meyer et al., 1998). The stress concentrations at the propagating 468 fault tips are often thought to explain why such fault cut across rheological boundaries rather than 469 progressively coalescing at the boundary between domains with contrasted rheologies (Hubert-Ferrari 470 et al., 2003). While we are lacking any direct evidence substantiating the propagation of EPGFZ, its 471 linear trace and actual localization cutting across very distinctive rheological domain suggest it has 472 been the case.

\section{7. Conclusions}

We imaged distinct structures in the Jamaica Passage thanks to high-resolution bathymetry 476 and seismic reflection data. We propose to interpret the half-grabens basins structures evidenced as 477 created during the Cayman margin rifting episode, thus delineating the easternmost part of the 478 Cayman Trough passive margin. These half-grabens have been deformed and folded afterward during

479 a phase of compression that could be related to a regional paleogeographic rearrangement at about 
$48020 \mathrm{Ma}$. In the south of these half-grabens, a distinct crustal domain is characterized by strong 481 horizontal parallel reflectors, possibly indicating the presence of Carib Beds typical of the CLIP. 482 The activity of the left-lateral strike-slip EPGFZ led to the formation of the Navassa asymmetrical 483 strike-slip related basin and is imaged in the Morant half-graben. All the inherited basins are 484 deformed during the activity of the EPGFZ indicating a compressive phase across the Jamaica 485 Passage, related to the transpressive tectonics along this plate boundary. Finally the trace of the 486 EPGFZ does not seem to be influenced by tectonic inheritance, since the transition between the 487 two crustal domains does not appear to represent a zone of weakness for fault localization. 488 


\section{Acknowledgements}

490 We thank the crew of the research vessel "L'Atalante" as well as Jean-Xavier Castrec of 491 IFREMER and Rémy Balcon of GENAVIR. We thank Bruno Asseray and the French Embassy in 492 Haiti. We are also grateful to the Bureau des Mines et de l'Energie, the SEMANAH, the Université 493 d'Etat d'Haiti, and particularly C. Prépetit, D. Boisson, and J. Jadotte for their support. We thank 494 two anonymous reviewers for their constructive comments that helped improved the 495 manuscript. Data used in this study are from the Haiti-SIS cruise

496 (http://dx.doi.org/10.17600/12010070).

497

498

499 Supplementary data to this article can be found online at:

500 http://dx.doi.org/10.1016/j.tecto.2016.03.022 . 
References

Abbott Jr, R. N., Bandy, B. R. and Rajkumar, A., 2013. Cenozoic burial metamorphism in eastern Jamaica, Caribbean Journal of Earth Science, 46, 13--30.

Armijo R., Meyer B., Hubert A. et Barka A., 1999. Westward propagation of the north anatolian fault into the northern aegean : Timing and kinematics, Geology, 27(3), pp. 267-270.

Armijo, R., Meyer, B., Navarro, S., King, G. and Barka, A., 2002. Asymmetric slip partitioning in the Sea of Marmara pull-apart: a clue to propagation processes of the North Anatolian Fault?, Terra Nova, 14(2), 80--86.

Bader, R.G., Gerard, R.D. and others, 1970. Initial Reports of the Deep Sea Drilling Project, Leg 4, U.S. Government Printing Office, Washington D.C.

Ben-Avraham, Z., 1992. Development of asymmetric basins along continental transform faults, Tectonophysics, 215(1), 209--220.

Ben-Avraham, Z. and Zoback, M.D., 1992. Transform-normal extension and asymmetric basins: An alternative to pull-apart models, Geology, 20(5), 423--426.

Benford, B., DeMets, C., Tikoff, B., Williams, P., Brown, L. and Wiggins-Grandison, M., 2012a. Seismic hazard along the southern boundary of the Gônave microplate: block modelling of GPS velocities from Jamaica and nearby islands, northern Caribbean, Geophysical Journal International, $190(1), 59-74$.

Benford, B., DeMets, C., \& Calais, E., 2012b. GPS estimates of microplate motions, northern Caribbean: evidence for a Hispaniola microplate and implications for earthquake hazard. Geophysical Journal International, 191(2), 481-490.

Bien-Aimé Momplaisir, R., 1986. Contribution to the Geologic Study of the Eastern Part of the Massif of La Hotte (Presqu'Ile du Sud d'Haiti). Structural Synthesis of the Margins of the Peninsula from Seismic Data. Doctoral thesis, Pierre et Marie Curie University, Paris, France.

Bowin, C., 1975. The geology of Hispaniola, pp. 501--552, Springer US.

Bowland, C. L., 1993. Depositional history of the Western C olombian B asin, C aribbean Sea, revealed by seismic stratigraphy, Geological Society of America Bulletin, 105(10), 1321-1345.

Bowland, C. L. and Rosencrantz, E., 1988. Upper crustal structure of the Western C olombian B asin, Caribbean Sea, Geological Society of America Bulletin, 100(4), 534--546.

Burke, K., Grippi, J. and Şengör, A. C., 1980. Neogene structures in Jamaica and the tectonic style of the Northern Caribbean plate boundary zone, The Journal of Geology, 375--386.

Calais, E., and Mercier de Lépinay, B., 1991. From transtension to transpression along the 
northern Caribbean plate boundary off Cuba: implications for the Recent motion of the Caribbean plate. Tectonophysics, 186(3-4), 329-350.

Calais, E. and Mercier de Lépinay, B., 1995. Strike-slip tectonic processes in the northern Caribbean between Cuba and Hispaniola (Windward Passage), Marine Geophysical Researches, 17(1), $63-95$.

Calais, E., Freed, A., Mattioli, G., Amelung, F., Jónsson, S., Jansma, P. and Momplaisir, R., 2010. Transpressional rupture of an unmapped fault during the 2010 Haiti earthquake. Nature Geoscience, 3(11), 794-799.

Calmus, T., 1983. Contribution à l'étude géologique du massif de Macaya (Sud-Ouest d'Haïti, Grandes Antilles), sa place dans l'évolution de l'orogène nord-carä̈be. PhD Thesis, Univ. Paris VI, France.

Case, J. E. and Holcombe, T. L., 1980. Geologic-tectonic map of the Caribbean region. United States Geological Survey.

Choi, E., Seeber, L., Steckler, M. S. and Buck, R., 2011. One-sided transform basins and "inverted curtains": Implications for releasing bends along strike-slip faults, Tectonics, 30(6).

Cruz-Orosa, I., Sàbat, F., Ramos, E., Rivero, L. and Vázquez-Taset, Y. M., 2012. Structural evolution of the La Trocha Fault zone: Oblique collision and strike-slip basins in the Cuban orogen, Tectonics, 31(5).

Diebold, J., Stoffa, P., Buhl, P. and Truchan, M., 1981. Venezuela basin crustal structure, Journal of Geophysical Research: Solid Earth (1978-2012), 86(B9), 7901—7923.

Diebold, J., Driscoll, N. and EW-9501-Science Team, 1999. New insights on the formation of the Caribbean basalt province revealed by multichannel seismic images of volcanic structures in the Venezuelan Basin. In: MANN, P. (ed.) Caribbean Basins. Sedimentary Basins of the World. Elsevier Science, Amsterdam, 561-589.

Dillon, W. P., Austin Jr, J. A., Scanlon, K. M., Terence Edgar, N. and Parson, L. M., 1992. Accretionary margin of north-western Hispaniola: morphology, structure and development of part of the northern Caribbean plate boundary, Marine and petroleum geology, 9(1), 70--88.

Draper, G., 1987. A revised tectonic model for the evolution of Jamaica. In Proceedings workshop on the status of Jamaican geology, Kingston, Geological Society of Jamaica, Special Issue, $151-169$.

Driscoll, N. W. and Diebold, J. B., 1999. Tectonic and stratigraphic development of the eastern Caribbean: new constraints from multichannel seismic data. Sedimentary Basins of the World, 4, 591626.

Duncan, R. and Hargraves, R., 1984. Plate tectonic evolution of the Caribbean region in 
the mantle reference frame, Geological Society of America Memoirs, 162, 81--94.

Edgar, N. T., Saunders, J.B. and others, 1973. Initial Report of the DSDP, Leg 15. U.S. Government Printing Office, Washington, D.C.

Goreau, P.D.E., 1981. The tectonic evolution of the north central Caribbean plate margin, Ph.D. Thesis, Woods Hole and Massachusetts Institute of Technology, 245 p.

Granja Bruña, J. L., Ten Brink, U. S., Carbó-Gorosabel, A., Muñoz-Martín, A. and Ballesteros, M. G., 2009. Morphotectonics of the central Muertos thrust belt and Muertos Trough (northeastern Caribbean). Marine geology, 263(1), 7-33.

Granja Bruña, J. L., Carbo-Gorosabel, A., Hernaiz-Huerta, P. P., Estrada, P. L., Muñoz-Martín, A. and Campos, A. O., 2011. El terremoto de Haití, Enseñanza de las Ciencias de la Tierra, 19(3), 369 -371 .

Granja Bruña, J. L., Carbó-Gorosabel, A., Estrada, P. L., Muñoz-Martín, A., Ten Brink, U. S., Ballesteros, M. G., and Pazos, A., 2014. Morphostructure at the junction between the Beata ridge and the Greater Antilles island arc (offshore Hispaniola southern slope). Tectonophysics, 618, 138-163.

Hastie, A. R., Kerr, A. C., Mitchell, S. F., and Millar, I. L., 2008. Geochemistry and petrogenesis of Cretaceous oceanic plateau lavas in eastern Jamaica. Lithos, 101(3), 323-343.

Hastie, A. R., Mitchell, S. F., Treloar, P. J., Kerr, A. C., Neill, I. and Barfod, D. N., 2013. Geochemical components in a Cretaceous island arc: The $\mathrm{Th} / \mathrm{La}-\left(\mathrm{Ce} / \mathrm{Ce}{ }^{*}\right) \mathrm{Nd}$ diagram and implications for subduction initiation in the inter-American region, Lithos, 162, 57--69.

Hayman, N. W., Grindlay, N. R., Perfit, M. R., Mann, P., Leroy, S. and de Lépinay, B. M., 2011. Oceanic core complex development at the ultraslow spreading Mid-Cayman Spreading Center, Geochemistry, Geophysics, Geosystems, 12(3).

Herron, D. A. and Latimer, R. B., 2011. First steps in seismic interpretation: SEG. Geophysical Monograph Series, 16.

Holcombe, T. L., Vogt, P. R., Matthews, J. E. and Murchison, R. R., 1973. Evidence for seafloor spreading in the Cayman Trough, Earth and Planetary Science Letters, 20(3), 357--371.

Hopkins, H.R., 1973. Geology of the Aruba Gap abyssal plain near DSDP site 153, Init. Rep. DSDP 15, 1039--1050.

Horsfield, W. and Robinson, E., 1974. Marine geology of the Jamaica Passage, Trans. 7th Caribb. Geol. Gonf, 107--113.

Hubert-Ferrari A., King G., Manighetti I., Armijo R., Meyer B. et Tapponnier P., 2003. Longterm elasticity in the continental lithosphere ; modelling the aden ridge propagation and the anatolian extrusion process, Geophysical Journal International, 153 (1), pp. 111-132. 
James-Williamson, S. A., Mitchell, S. F. and Ramsook, R., 2014. Tectono-stratigraphic development of the Coastal Group of south-eastern Jamaica, Journal of South American Earth Sciences, 50, 40-47.

Kroehler, M. E., Mann, P., Escalona, A. and Christeson, G., 2011. Late Cretaceous-Miocene diachronous onset of back thrusting along the South Caribbean deformed belt and its importance for understanding processes of arc collision and crustal growth. Tectonics, 30(6).

Ladd, J. W. and Watkins, J. S., 1980. Seismic stratigraphy of the Western Venezuela B asin, Marine Geology, 35(1), 21--41.

Ladd, J. W., Holcombe, T. L., Westbrook, G. K. and Edgar, N. T., 1990. Caribbean marine geology; active margins of the plate boundary, in The Geology of North America, The Caribbean Region, v. H, pp. 261--290, ed. Dengo G. and Case, J. E., Boulder, Colorado, Geological Society of America.

Leroy, S., Mercier de Lépinay, B., Mauffret, A. and Pubellier, M., 1996. Structural and tectonic evolution of the eastern Cayman Trough (Caribbean $\mathrm{S}$ ea) from seismic reflection data, AAPG Bulletin, 80(2), 222-247.

Leroy, S. and A. Mauffret, 1996. Intraplate deformation in the Caribbean region, Journal of Geodynamics, vol. 21, no 1, p. 113-122.

Leroy, S., Mauffret, A., Patriat, P. and Mercier de Lépinay, B., 2000. An alternative interpretation of the Cayman Trough evolution from a reidentification of magnetic anomalies, Geophysical Journal International, 141(3), 539--557.

Leroy S., Ellouz-Zimmermann, N., Corbeau, J., Rolandone, F., Mercier de Lépinay, B., Meyer, B., Momplaisir, R., Granja Bruña, J. L., Battani, A., Baurion, C., Burov, E., Clouard, V., Deschamps, R., Gorini, C., Hamon, Y., Lafosse, M., Leonel, J., Le Pourhiet, L., Llanes, P., Loget, N., Lucazeau, F., Pillot, D., Poort, J., Tankoo, K., Cuevas, J.-L., Alcaide, J. F., Jean Poix, C., Muñoz-Martín, A., Mitton, S., Rodriguez, Y., Schmitz, J., Seeber, L., Carbo-Gorosabel, A. and Muñoz S., 2015. Segmentation and kinematics of the North America-Caribbean plate boundary offshore Hispaniola, Terra Nova.

Lewis, J. F. and Draper, G., 1990. Geology and tectonic evolution of the northern Caribbean margin, in The Geology of North America, The Caribbean region, v. H, pp. 77--140, ed. Dengo G. and Case, J. E., Boulder, Colorado, Geological Society of America.

Lu, R. and McMillen, K., 1982. Multichannel seismic survey of the Colombia B asin and adjacent margins, Studies in Continental Margin Geology, 395-410.

Manaker, D. M., Calais, E., Freed, A. M., Ali, S. T., Przybylski, P., Mattioli, G. and De Chabalier, J. B., 2008. Interseismic plate coupling and strain partitioning in the northeastern Caribbean. Geophysical Journal International, 174(3), 889-903.

Mann, P., Draper, G. and Burke, K., 1985. Neotectonics of a strike-slip restraining bend system, 
Jamaica, The Society of Economic Paleontologists and Mineralogists, 211--226.

Mann, P. and Burke, K., 1990. Transverse intra-arc rifting: Palaeogene Wagwater Belt, Jamaica, Marine and Petroleum Geology, 7(4), 410--427.

Mann, P., Taylor, F., Edwards, R. L. and Ku, T.-L., 1995 . Actively evolving microplate formation by oblique collision and sideways motion along strike-slip faults: An example from the north- eastern Caribbean plate margin, Tectonophysics, 246(1), 1--69.

Mann, P., Calais, E., Ruegg, J.-C., DeMets, C., Jansma, P. E. and Mattioli, G. S., 2002. Oblique collision in the northeastern Caribbean from GPS measurements and geological observations, Tectonics, 21(6), 1057.

Mann, P., 1997. Model for the formation of large, transtensional basins in zones of tectonic escape, Geology, 25(3), 211--214.

Mauffret, A. and Leroy, S., 1997. Seismic stratigraphy and structure of the Caribbean I gneous Province, Tectonophysics, 283(1), 61--104.

Mauffret, A. and Leroy, S., 1999. Neogene intraplate deformation of the Caribbean plate at the Beata Ridge, Sedimentary Basins of the World, 4, 627-669.

Mauffret, A., Leroy, S., d'Acremont, E., Maillard, A., Mercier de Lépinay, B., A. T. Dos Reis, N. Miller, A. Nercessian, R. Pérez-Vega et D. Perez, 2001. Une coupe de la province volcanique Caraïbe : premiers résultats de la campagne sismique Casis 2, Comptes Rendus de l'Académie des Sciences-Series IIA-Earth and Planetary Science, vol. 333, no 10, p. 659-667.

Meyer B., Tapponnier P., Bourjot L., Metivier F., Gaudemer Y., Peltzer G., Shunmin G. et Zhitai C., 1998. Crustal thickening in gansu-qinghai, lithospheric mantlesubduction, and oblique, strike-slip controlled growth of the tibet plateau, Geophysical Journal International, 135(1), pp. 1-47.

Peltzer G. et Tapponnier P., 1988. Formation and evolution of strike-slip faults, rifts, and basins during the India-Asia collision : an experimental approach, J. Geophys. Res., 93, pp. 15085-15117.

Prather, B. E., Pirmez, C., and Winker, C. D., 2012. Stratigraphy of linked intraslope basins: Brazos-Trinity system western Gulf of Mexico. Application of the Principles of Seismic Geomorphology to Continental-Slope and Base-of-Slope Systems: Case Studies from Seafloor and Near-Seafloor Analogues: SEPM, Special Publication, 99, 83-109.

Pindell, J. L. and Barrett, S. F., 1990. Geological evolution of the Caribbean region: a plate tectonic perspective, in Geology of North America, The Caribbean region, v. H, pp. 405-432, ed. Dengo G. and Case, J. E., Boulder, Colorado, Geological Society of America.

Pindell, J., Maresch, W. V., Martens, U. and Stanek, K., 2012. The Greater Antillean Arc: Early Cretaceous origin and proposed relationship to Central American subduction mélanges: implications for models of Caribbean evolution, International Geology Review, 54(2), 131--143. 
Pubellier, M., Mauffret, A., Leroy, S., Vila, J. M. and Amilcar, H., 2000. Plate boundary readjustment in oblique convergence: Example of the Neogene of Hispaniola, Greater Antilles, Tectonics, 19(4), 630--648.

Robinson, E. and Cambray, F. W., 1971. Physiography of the sea floor east of Jamaica, in Symposium on Investigations and Resources of the Caribbean Sea and Adjacent Regions, pp. 285--289, UNESCO Paris.

Rosencrantz, E. and Sclater, J. G., 1986. Depth and age in the Cayman Trough. Earth and Planetary Science Letters, 79(1), 133-144.

Rosencrantz, E., Ross, M. I., and Sclater, J. G., 1988. Age and spreading history of the Cayman Trough as determined from depth, heat flow, and magnetic anomalies. Journal of Geophysical Research: Solid Earth (1978-2012), 93(B3), 2141-2157.

Rosencrantz, E. and Mann, P., 1991. SeaMARC II mapping of transform faults in the Cayman Trough, Caribbean Sea. Geology, 19(7), 690--693.

Seeber, L., Sorlien, C., Steckler, M. and Cormier, M. H., 2010. Continental transform basins: Why are they asymmetric?, Eos, Transactions American Geophysical Union, 91(4), 29-30.

Sen, G., Hickey-Vargas, R., Waggoner, D. G. and Maurrasse, F., 1988. Geochemistry of basalts from the Dumisseau Formation, southern Haiti: implications for the origin of the Caribbean Sea crust. Earth and Planetary Science Letters, 87(4), 423-437.

Symithe, S., Calais, E., Chabalier, J. B., Robertson, R. and Higgins, M., 2015. Current block motions and strain accumulation on active faults in the Caribbean. Journal of Geophysical Research: Solid Earth, 120(5), 3748-3774.

Stoffa, P. L., Mauffret, A., Truchan, M. and Buhl, P., 1981. Sub-B layering in the southern Caribbean: the Aruba Gap and Venezuela Basin, Earth and Planetary Science Letters, 53(2), $131--146$.

Sykes, L. R., McCann, W. R. and Kafka, A. L., 1982 . Motion of Caribbean plate during last 7 million years and implications for earlier cenozoic movements, Journal of Geophysical Research: Solid Earth (1978-2012), 87(B13), 10656--10676.

Van Der Lelij, R., 2013. Reconstructing north-western Gondwana with implications for the evolution of the Iapetus and Rheic Oceans: a geochronological, thermochronological and geochemical study, PhD thesis, University of Geneva, Switzerland.

Wadge, G. and Dixon, T., 1984. A geological interpretation of seasat-sar imagery of Jamaica, The Journal of Geology, 561--581. 


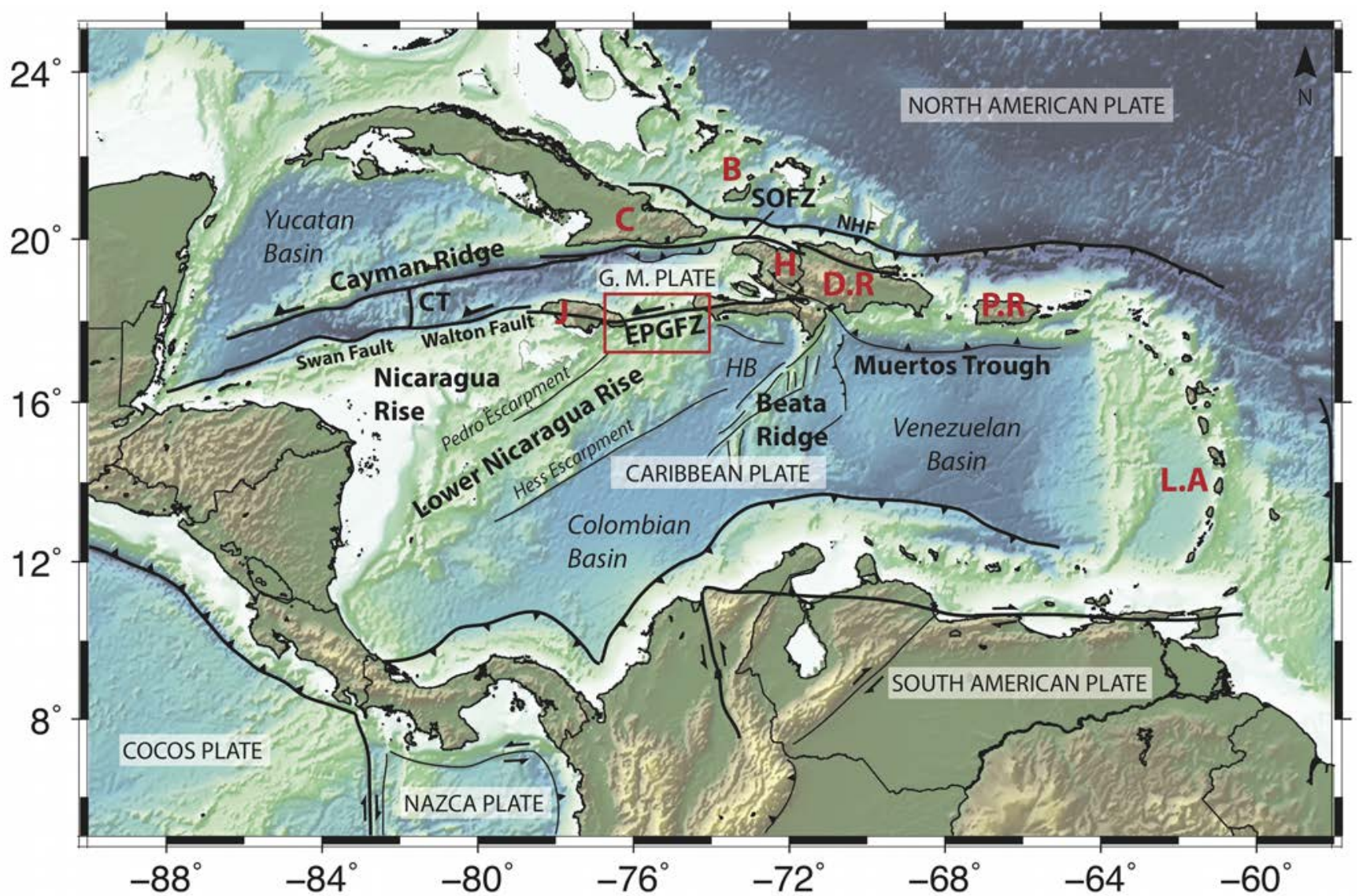

Figure 1: Tectonic map of the Caribbean. CT: Cayman Trough, EPGFZ: Enriquillo-Plantain-Garden Fault Zone, SOFZ: Septentrional-Oriente Fault Zone, NHF: North Hispaniola Fault, C: Cuba, J: Jamaica, B: Bahamas, H: Haiti, D.R: Dominican Republic, P.R: Puerto Rico, L.A: Lesser Antilles, G. M. PLATE: Gonâve micro-plate, HB: Haitian sub-basin. The red rectangle indicates the study area. Topography and bathymetry are from the 2 arc-minute global relief of Earth's surface ETOPO. 


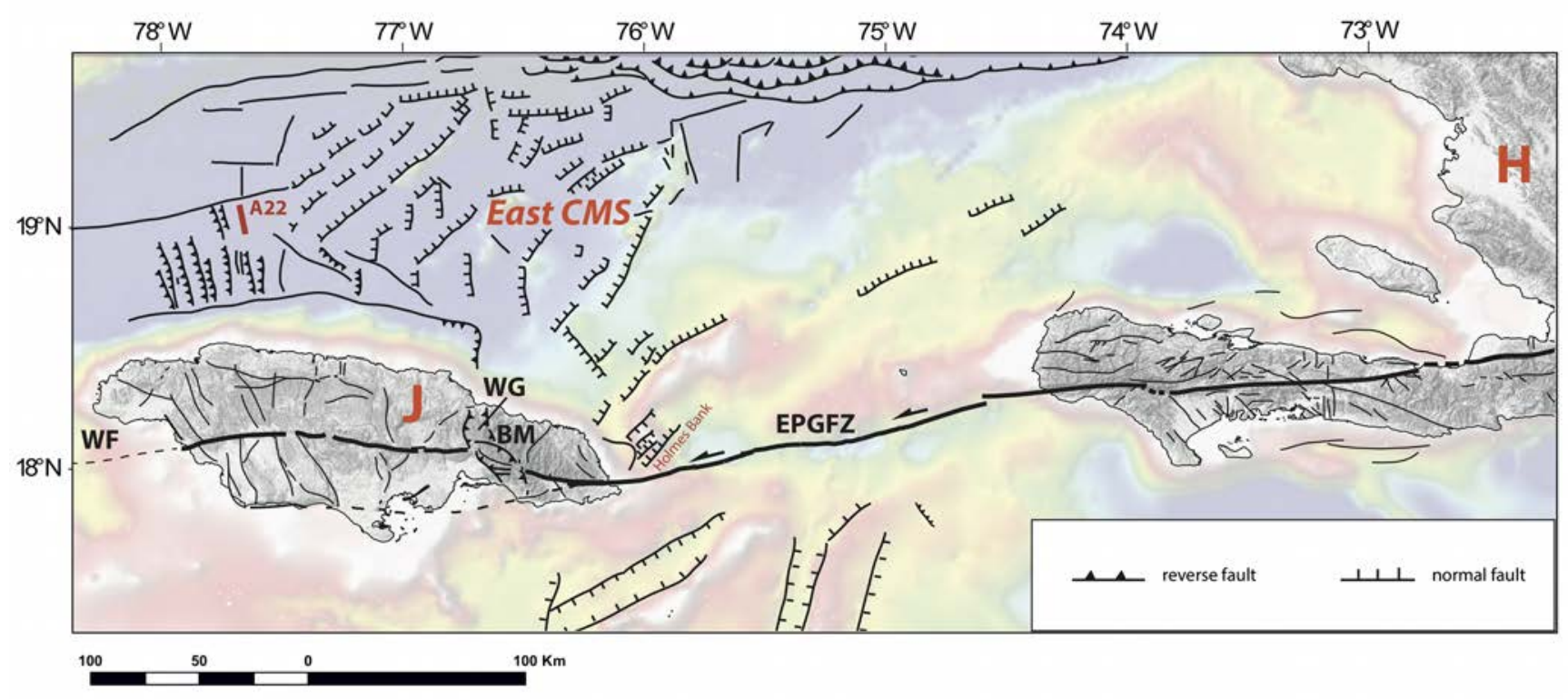

Figure 2: Synthetic structural map of the study area. Faults are from Bien-Aimé Momplaisir (1986), Calais and Mercier de Lépinay (1991), Leroy et al. (1996 and 2000), Granja Bruña et al. (2011) and Benford et al. (2012a). J: Jamaica, H: Hispaniola, East CMS: Eastern Cayman Margin System. WF: Walton Fault, WG: Wagwater Graben, BM: Blue Mountains, HB: Holmes Bank, EPGFZ: EnriquilloPlantain-Garden Fault Zone. A22: magnetic anomaly 22 ( 49 Ma, Leroy et al., 2000). 

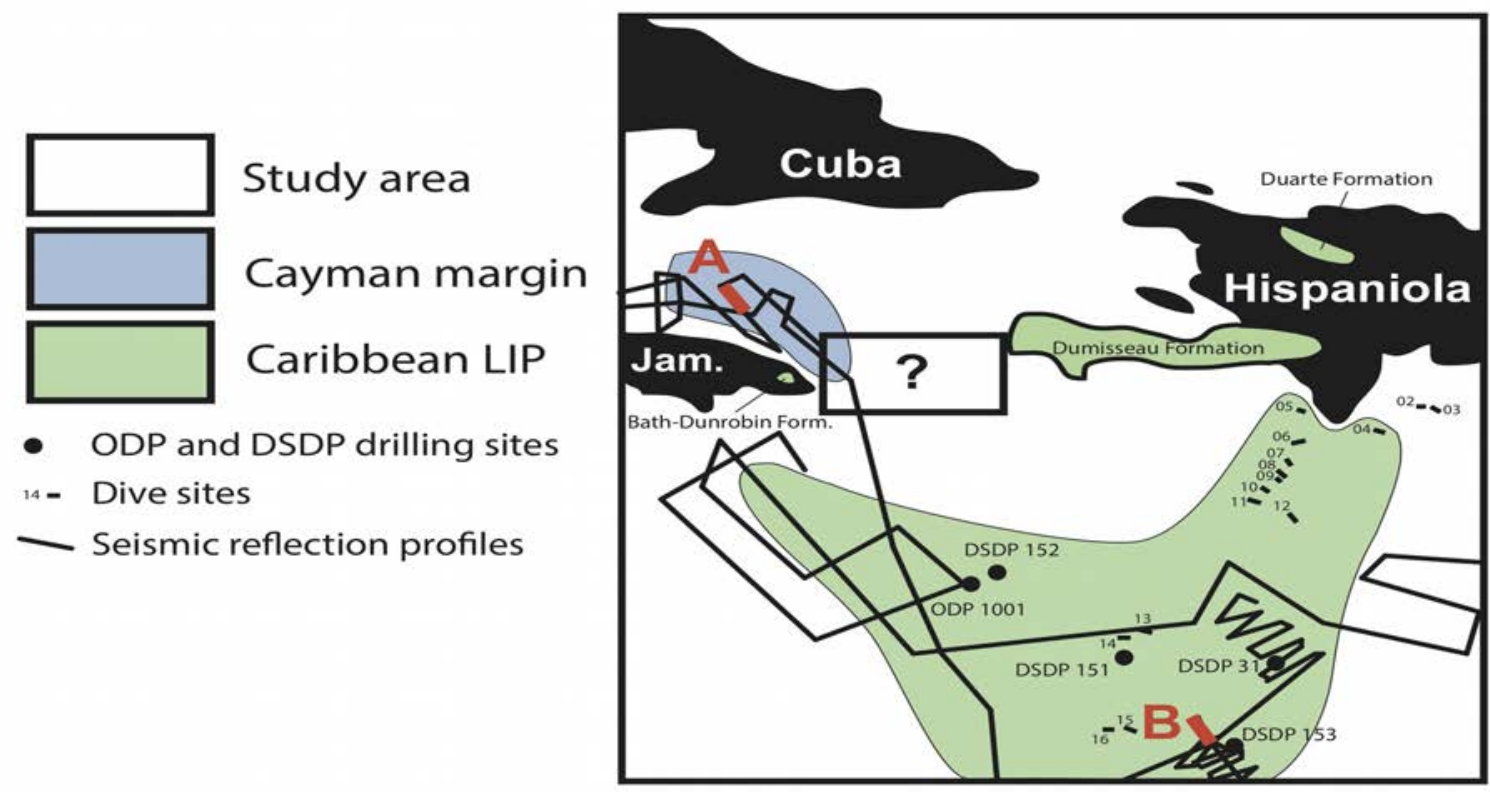

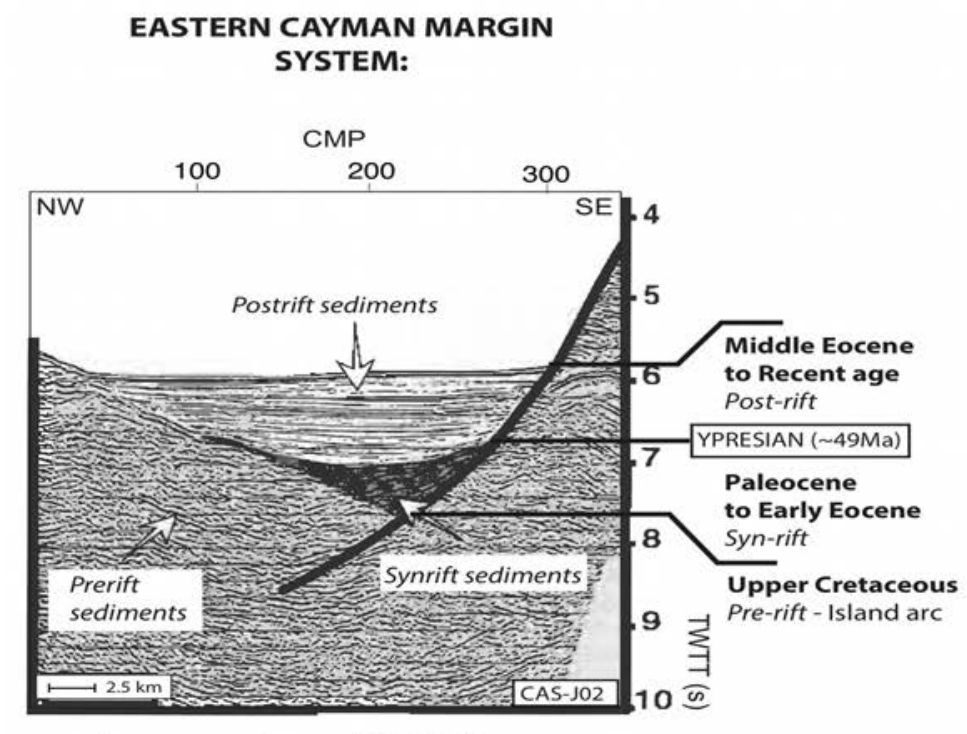

Leroy et al. (1996)

(A) CAS-J02

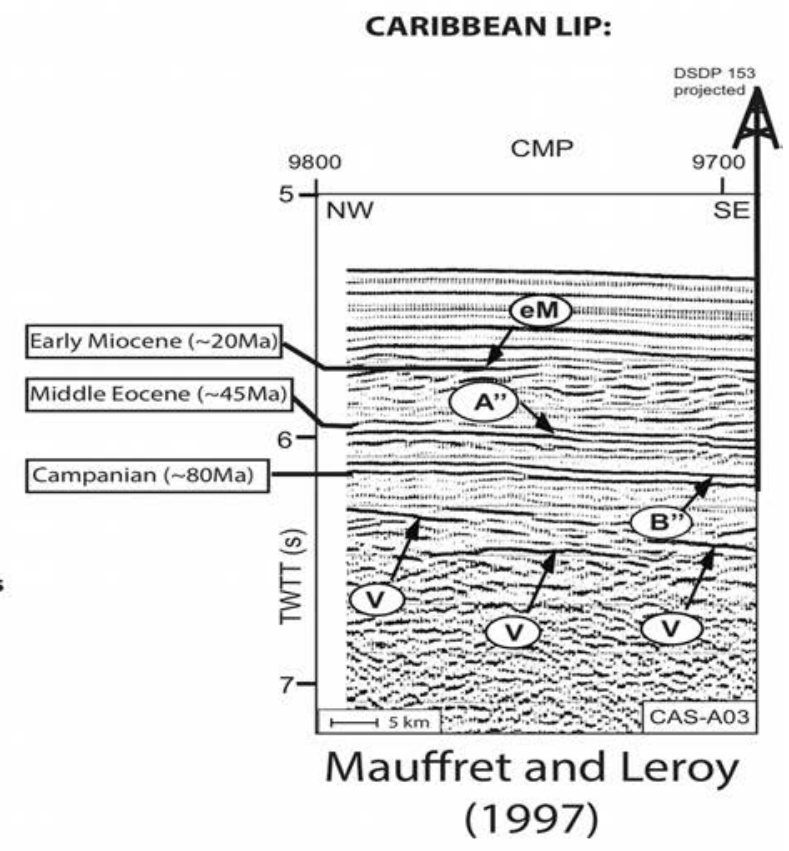

(B) CAS-A03

Figure 3: Map of the extent of the identified Caribbean LIP and eastern Cayman Trough passive margin. The identification of the Caribbean LIP is based on offshore on reflection seismic profiles, DSDP and ODP drills and submersible diving (Edgar et al., 1973; Mauffret and Leroy, 1997, Mauffret et al., 2001) and is based onshore on outcrops (Sen et al., 1988; Hastie et al., 2008). The identification of structures of the eastern Cayman Trough passive margin is based on reflection seismic profiles and correlations with onshore formations in Jamaica (Leroy et al., 1996). Published seismic stratigraphic sequences (A) in North Jamaica (Leroy et al., 1996; CAS-J02) and (B) in the Caribbean LIP (Mauffret and Leroy, 1997; CAS-A03). See text for detailed description of the seismic units. 


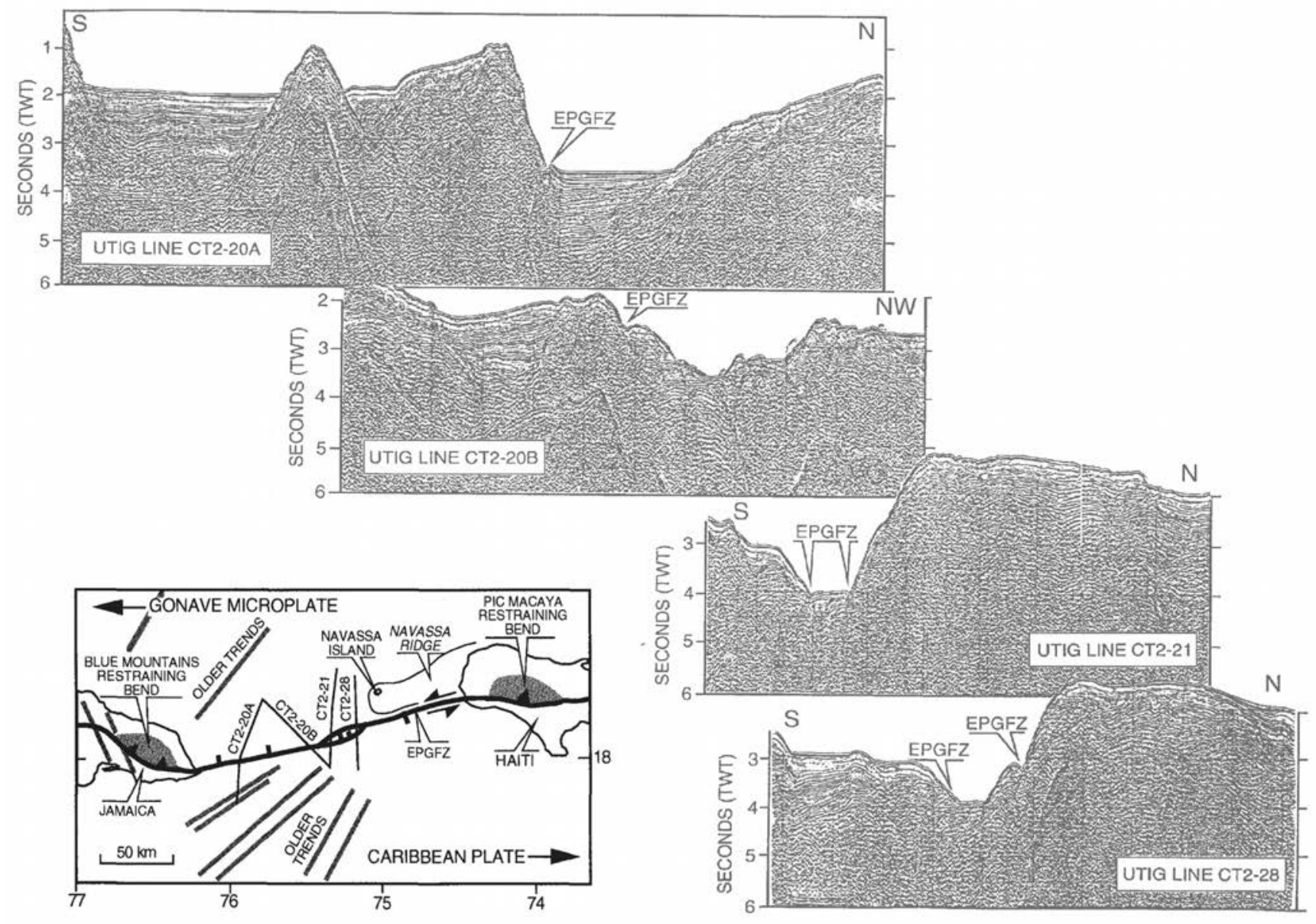

Figure 4: Four seismic reflection lines and the proposed trace of the EPGFZ in the Jamaica Passage from Mann et al. (1995). The positions of the four seismic profiles are also displayed in Fig. 5. 


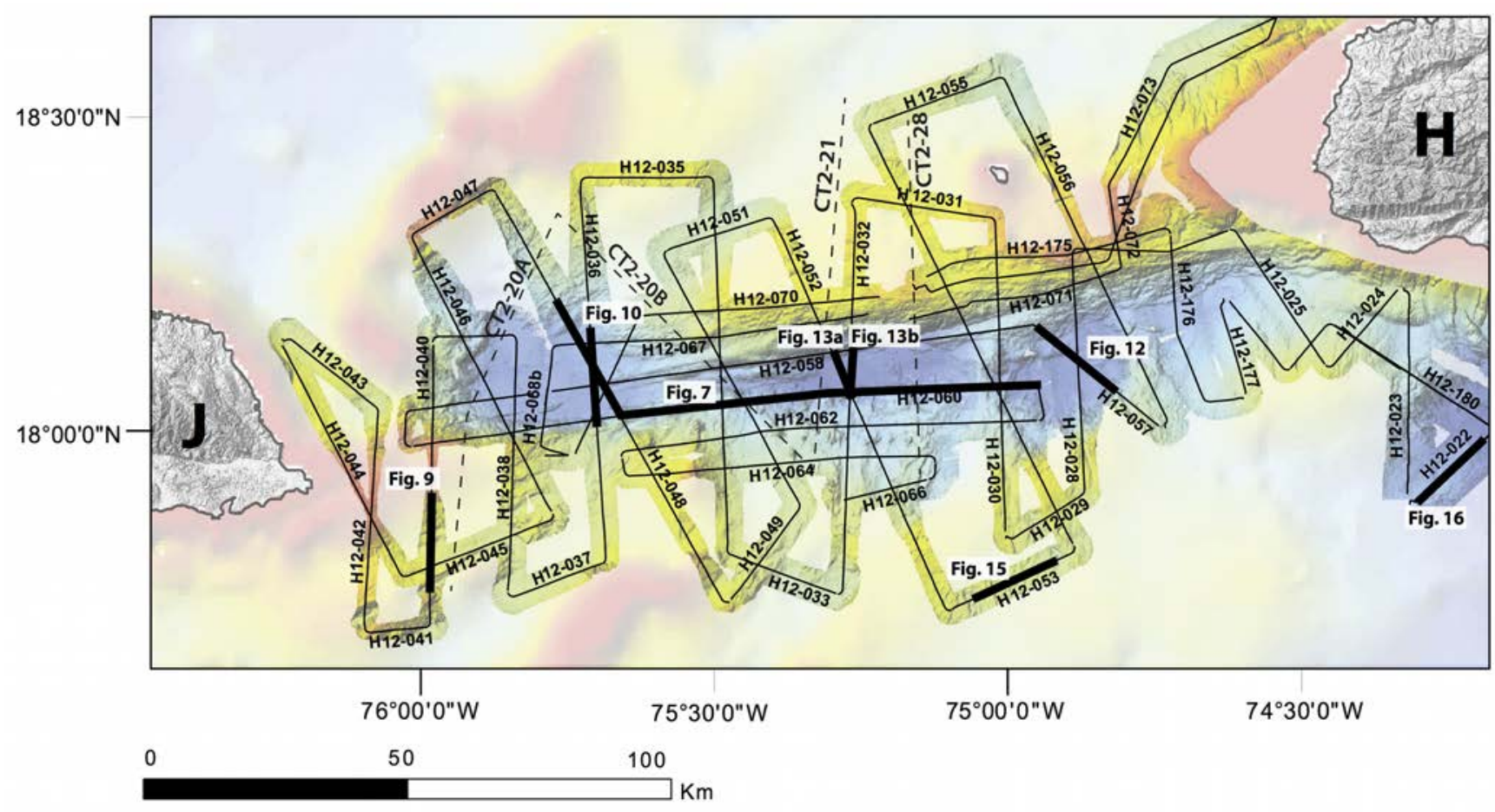

Figure 5: Track map of the HAITI-SIS cruise in the Jamaica Passage drown on the bathymetric map. J: Jamaica; H: Hispaniola. The thick solid lines represent the location of the interpreted seismic profiles showed in this paper. The dashed lines are the tracklines of the four seismic reflection profiles reported in Mann et al. (1995) and shown in Figure 4. 


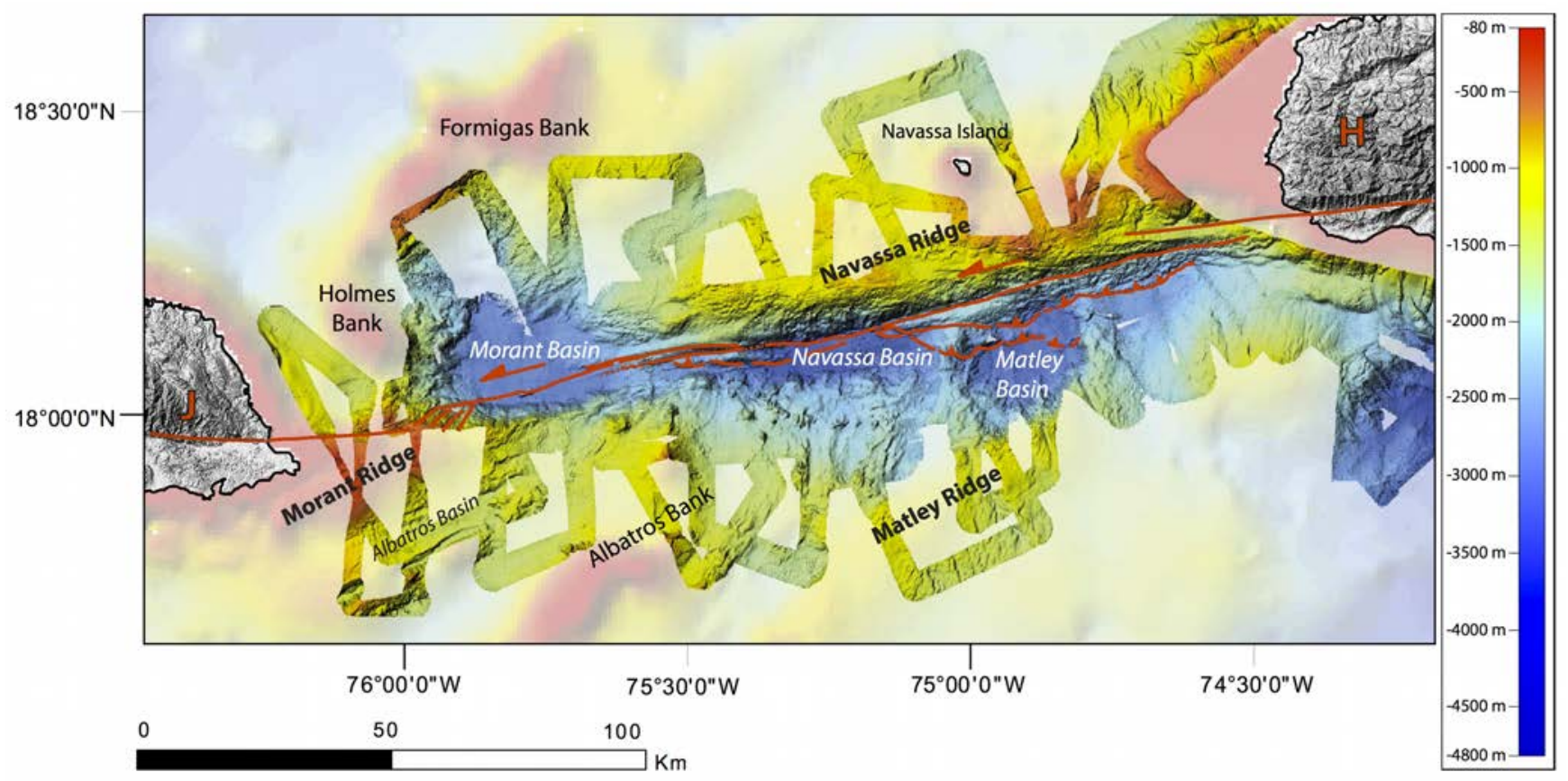

Figure 6: High-resolution bathymetric map of the Jamaica Passage and nomenclature of the major physiographic features. Main active EPGFZ structure is shown in red (Leroy et al., 2015). J: Jamaica, H: Hispaniola. The red line represents the present active trace of the Enriquillo-Plantain-Garden Fault Zone (EPGFZ).

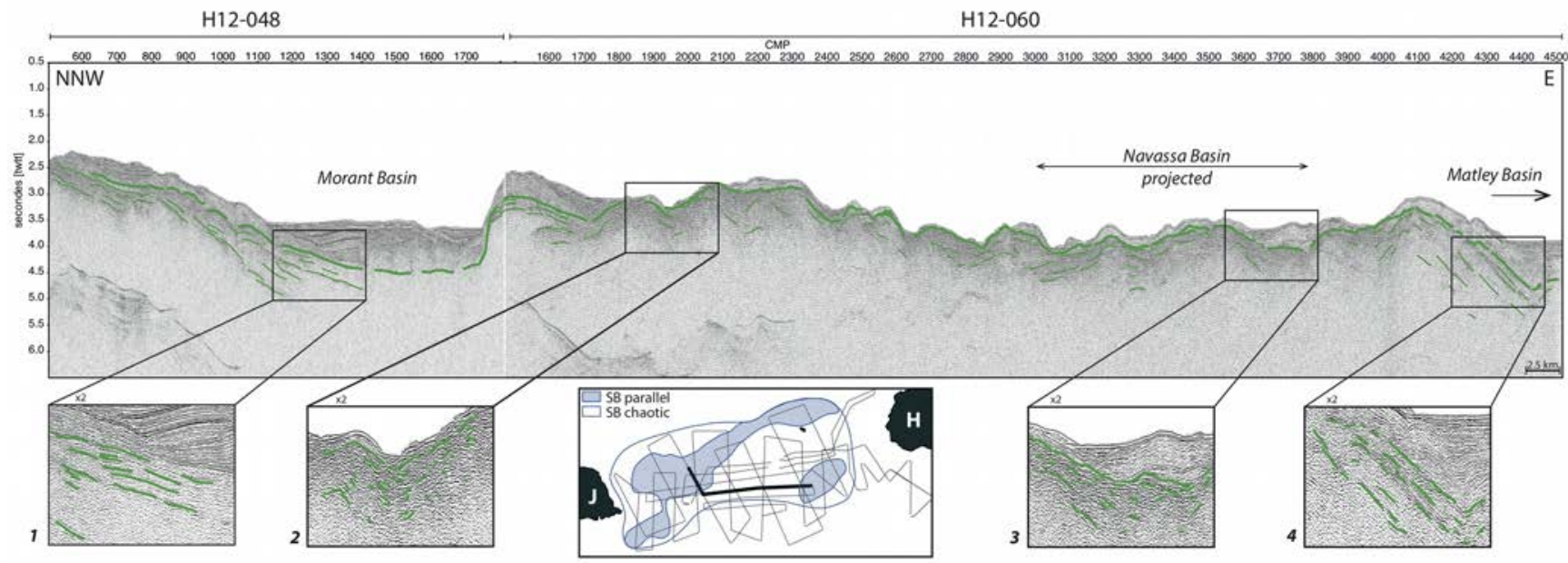

Figure 7: Interpreted seismic profiles HT12-060 and HT12-048 showing the continuous top of the acoustic basement (heavy green line) and the seismic basement below (SB unit, thin green lines). Enlarge views of the SB unit show its different facies: views 1 and 4, parallel facies; view 2 and 3, chaotic facies. See Fig. 5 for detailed location of the seismic profiles. The inset map shows the repartition of the two distinct facies of SB in the Jamaica Passage. 


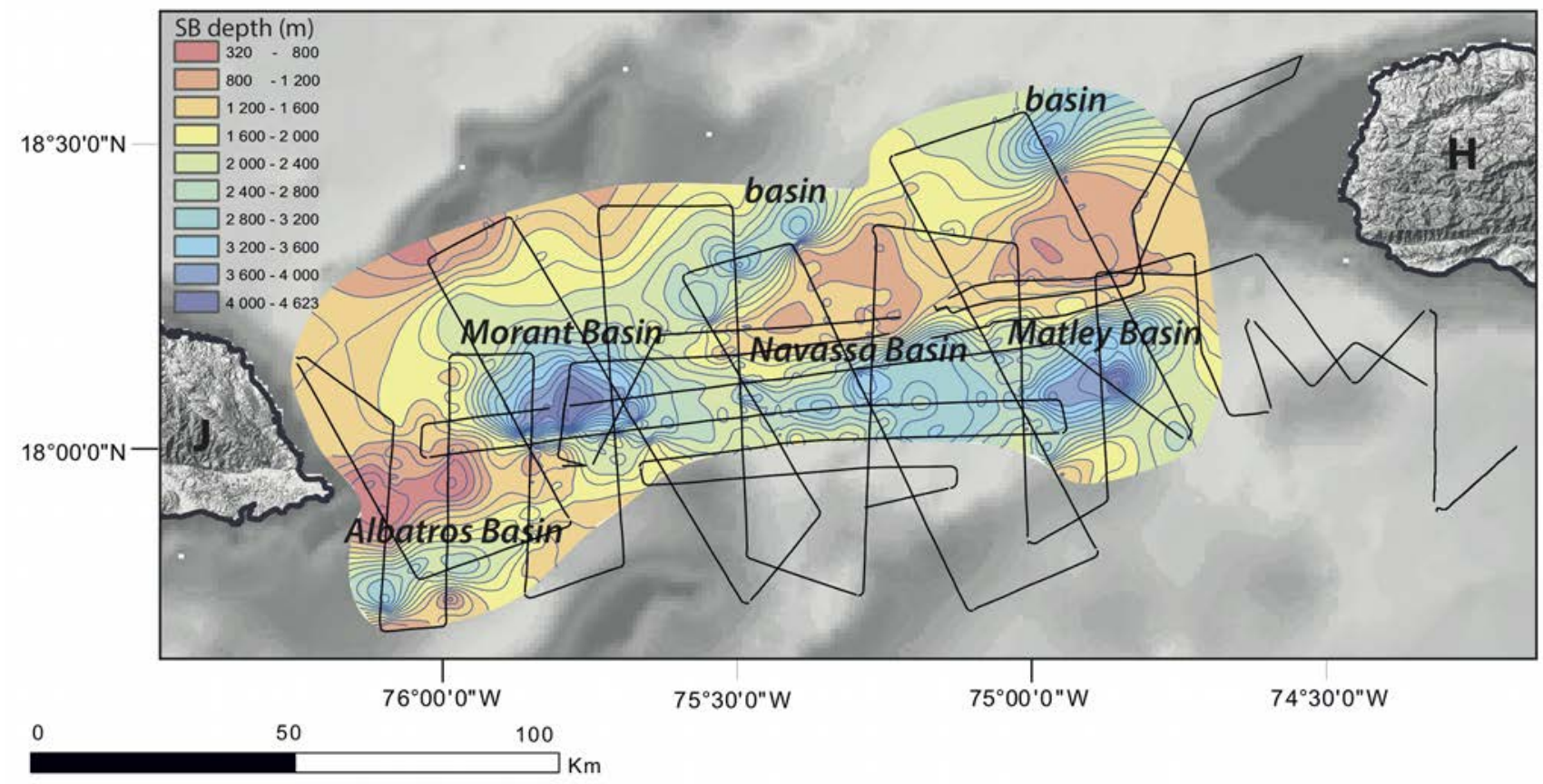

Figure 8: Depth to basement map. The basement is defined as the top of the seismic unit SB (see text for explanations). The color scale indicates the depths in meters that are interpolated from the dense seismic coverage. Depths are calculated with a velocity of $1500 \mathrm{~m} / \mathrm{s}$ for the water layer (sea level-sea bottom interval) and $2200 \mathrm{~m} / \mathrm{s}$ for sediments (seafloor-top of SB unit interval). The contour interval is $200 \mathrm{~m}$. The thin lines represent the tracklines of the seismic profiles. J: Jamaica; H: Hispaniola. 


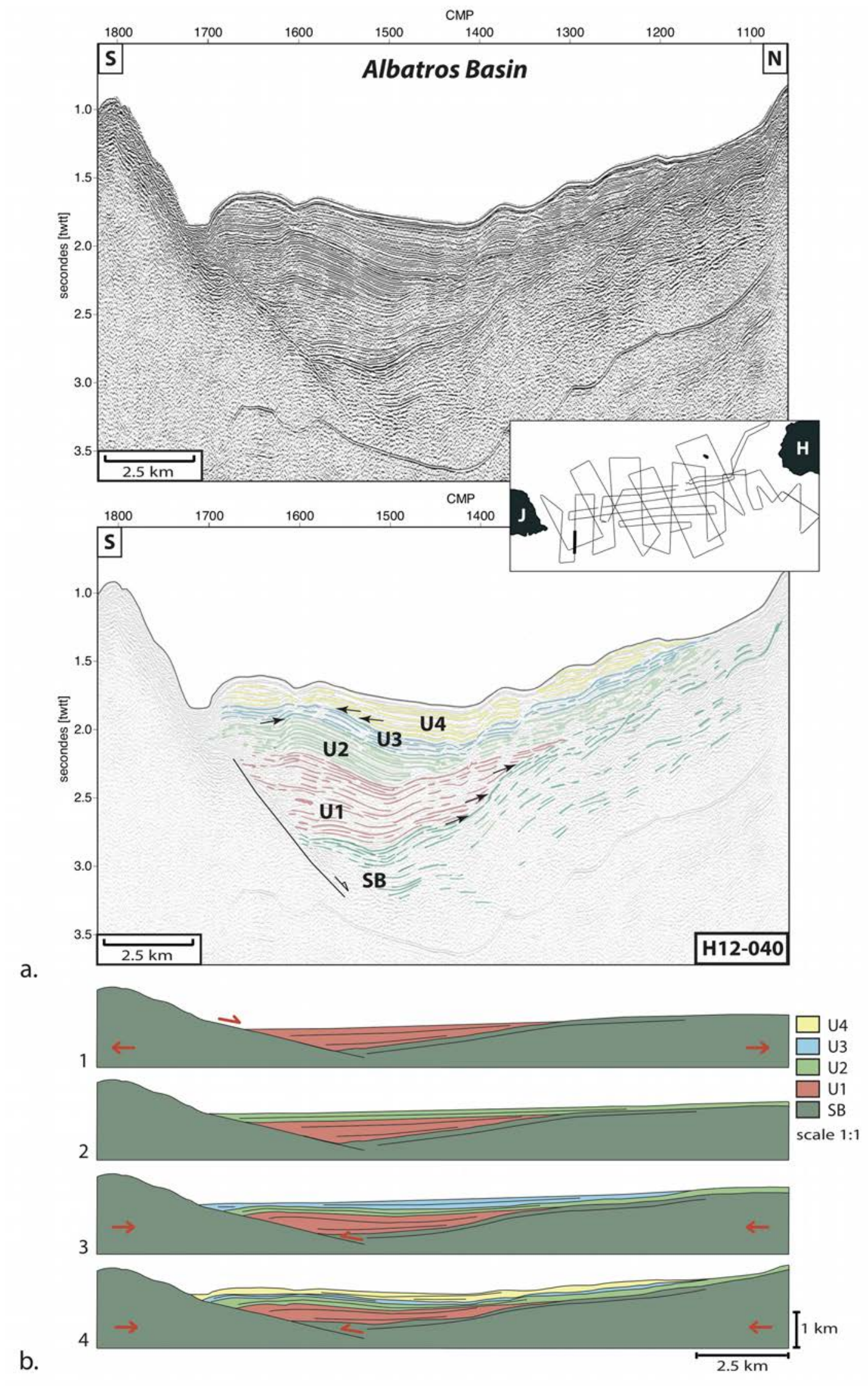


Figure 9: a. Detail of seismic profile H12-040 (upper panel) and its interpretation (lower panel). Black arrows show unconformities and onlaps. See inset and Fig. 5 for location. b. Sketch of the formation of the Albatros Basin at scale 1:1. Small topographic steps between CMP 1200-1400 correspond to gravitational unrooted normal faults without regional kinematics significance. See text for a detailed description in Section 5.2.2. 


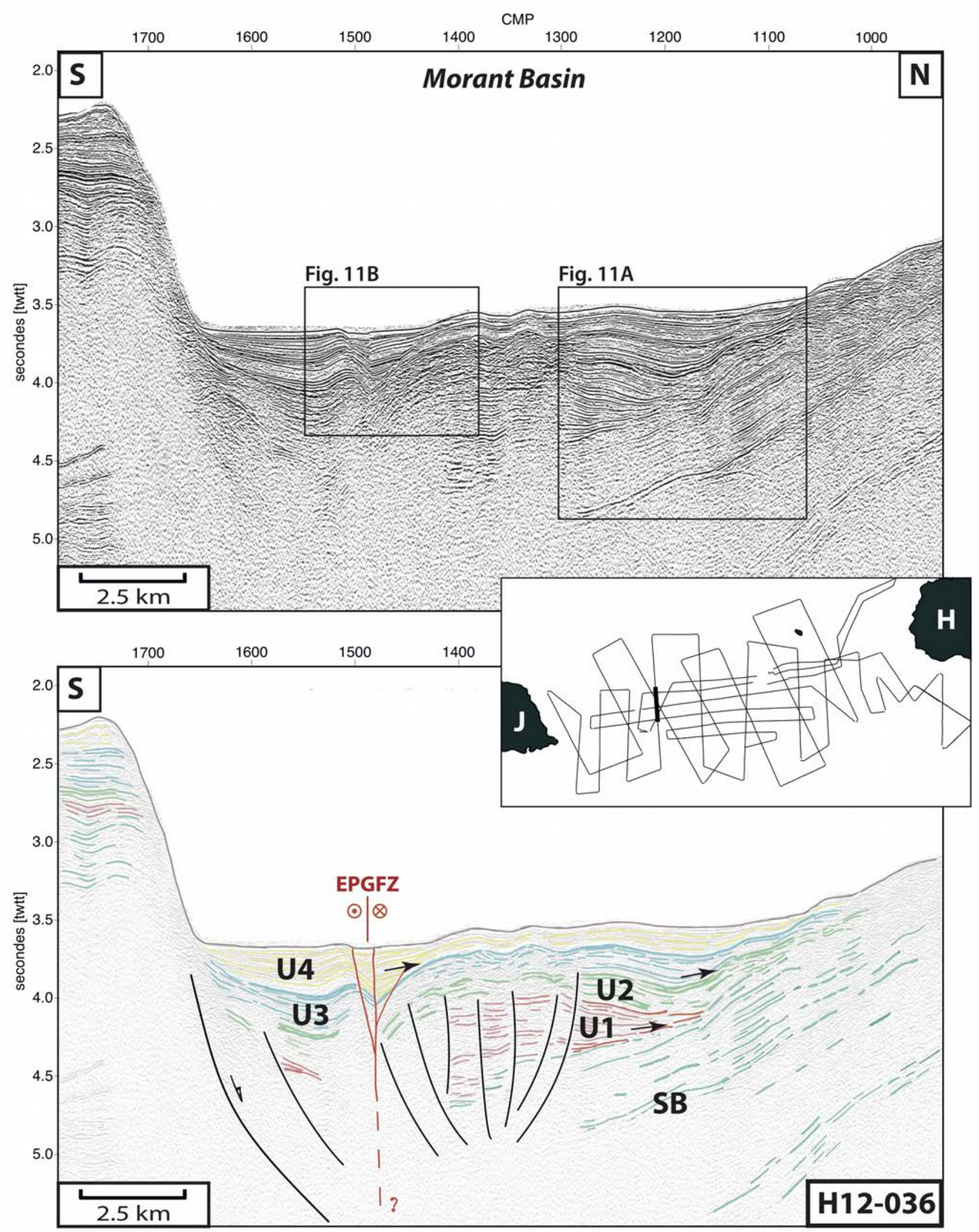


Figure 10: Detail of seismic profile H12-036 crossing the Morant Basin (upper panel) and its interpretation (lower panel). Black arrows show unconformities and onlaps. See inset and Fig. 5 for detailed location.

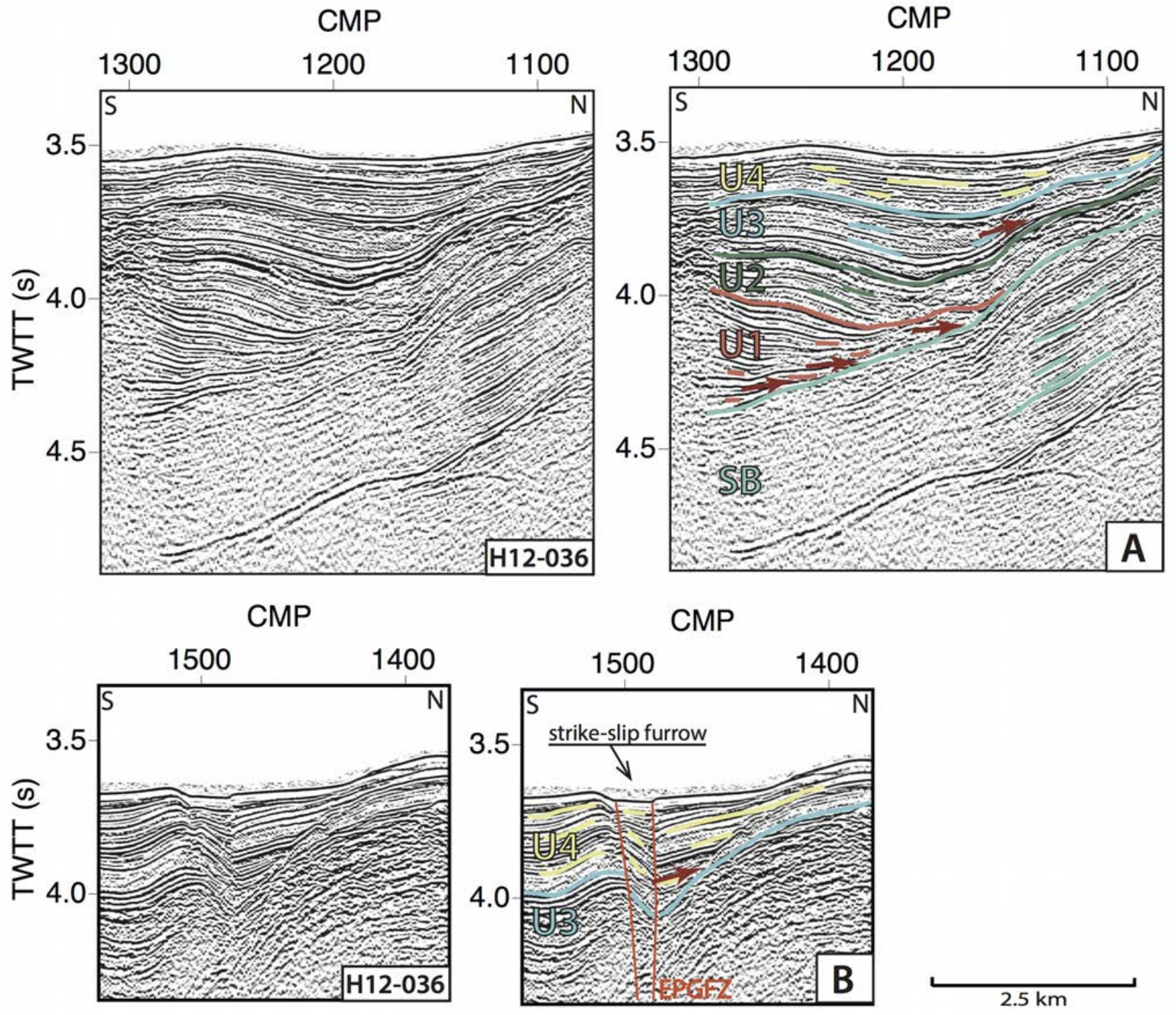

Figure 11: Enlarged images of the unconformities between the seismic units identified on profile H12036. See Fig. 10 for close-up locations. A: unconformities and onlaps (red arrows) between the SB and U1 units, and between U2 and U3 units. B: unconformity and onlaps (red arrows) between the upper units U3 and U4. The red lines indicate the present-day position of the EPGFZ. 


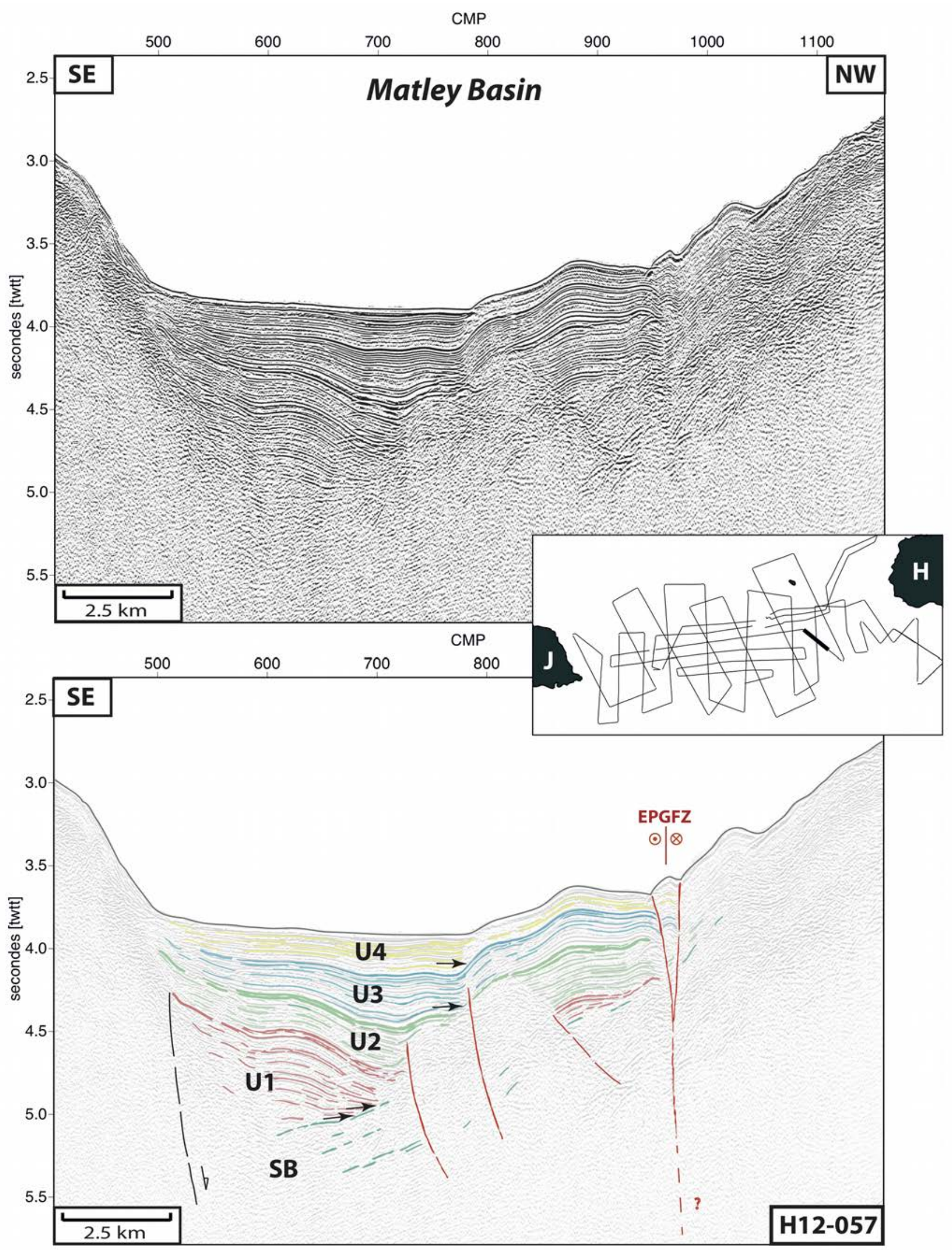


Figure 12: Detail of seismic profile H12-057 crossing the Matley Basin (upper panel) and its interpretation (lower panel). Black arrows show unconformities and onlaps. See inset and Fig. 5 for location. 


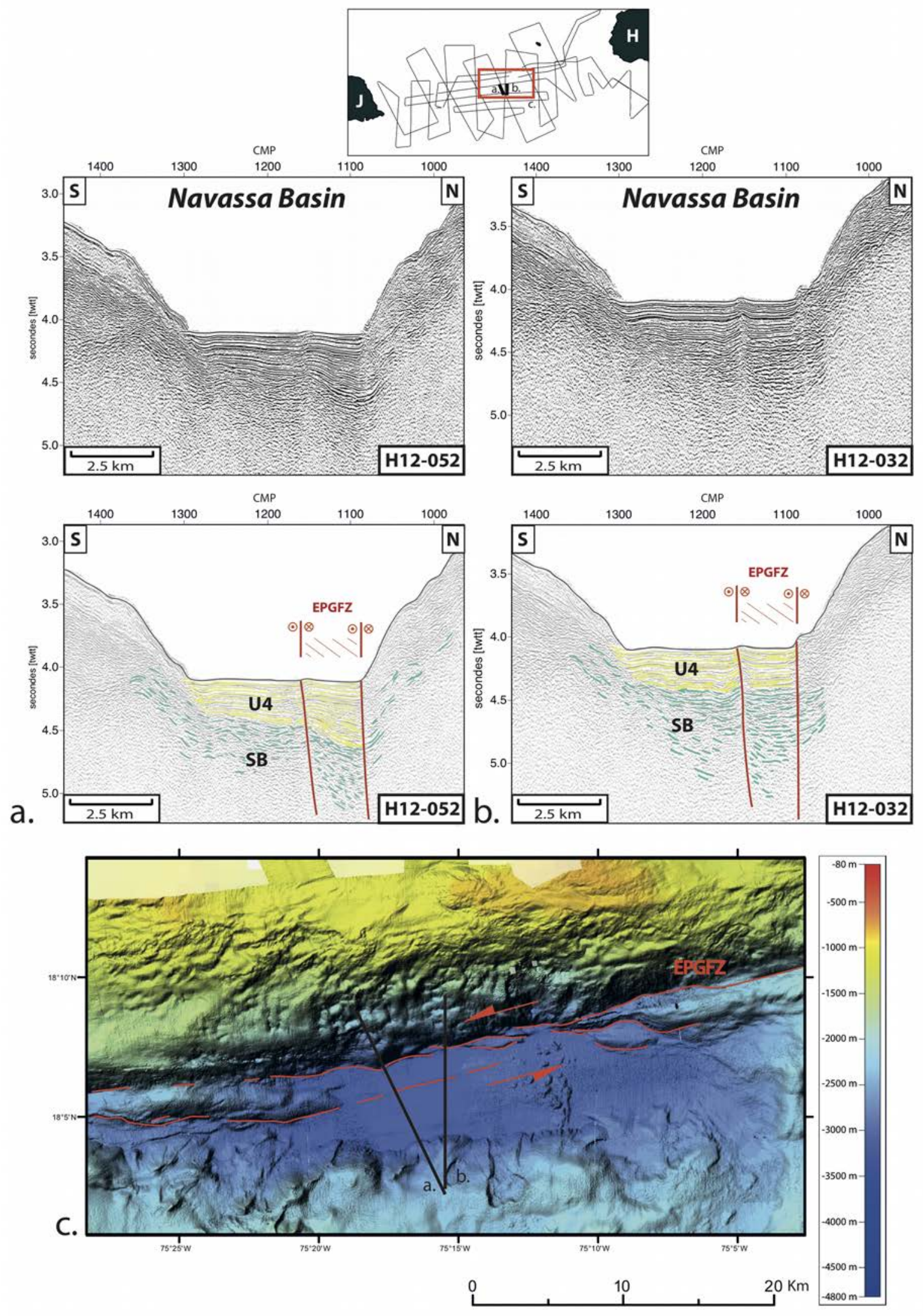


Figure 13: a: Detail of seismic profile H12-052 crossing the Navassa Basin (upper panel) and its interpretation (lower panel). b: Detail of seismic profile H12-032 crossing the Navassa Basin (upper panel) and its interpretation (lower panel). c: Enlarged view of the bathymetric map. See inset and Fig. 5 for location.
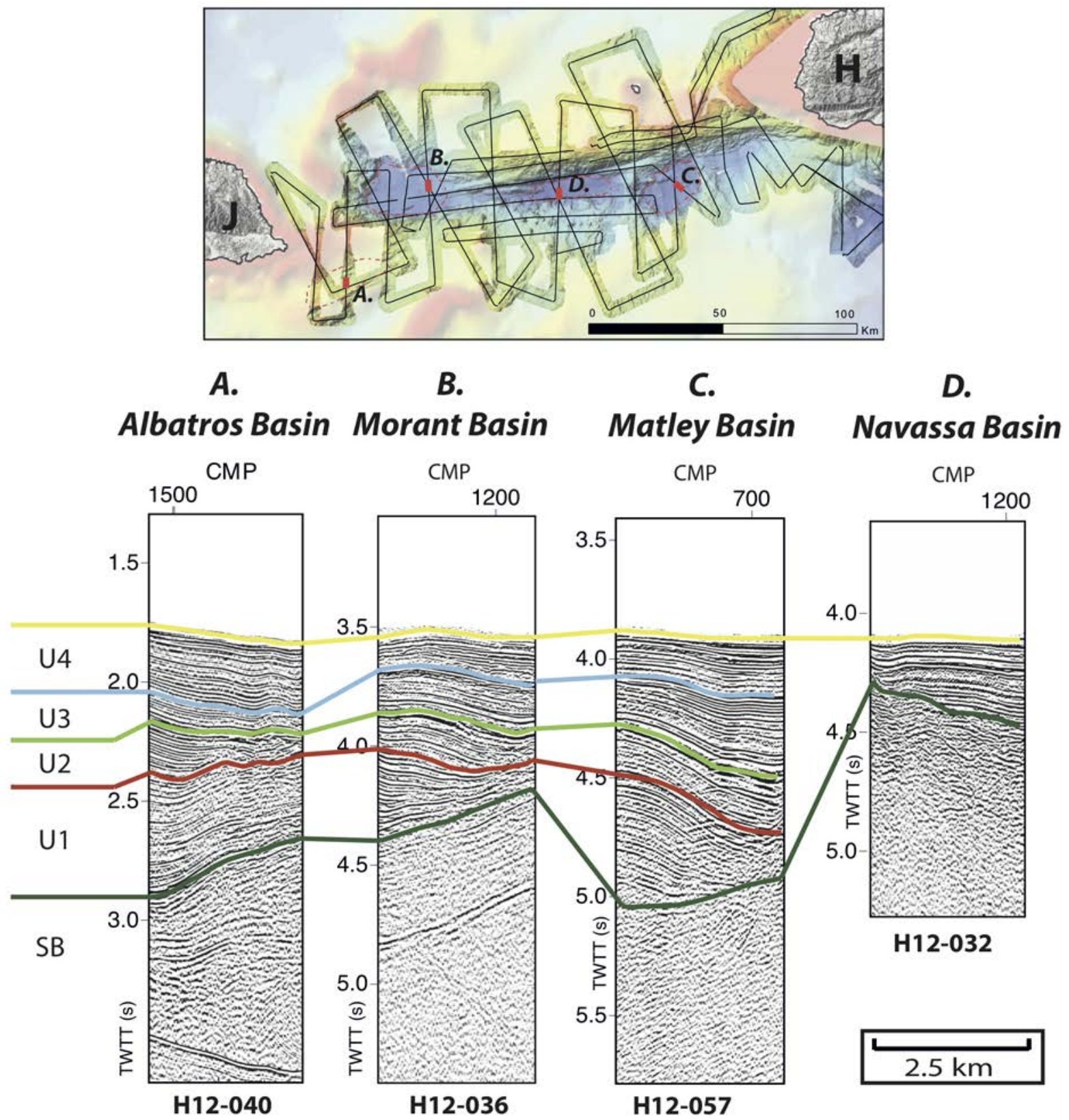

Figure 14: Synthesis of the seismic sequences identified in the three major basins of the Jamaica Passage, and seismic facies correlation between the four basins. In the Navassa Basin, only the upper sequence U4 is identified overlying the acoustic substratum SB. Red dotted lines in the map show the locations of the basins. 


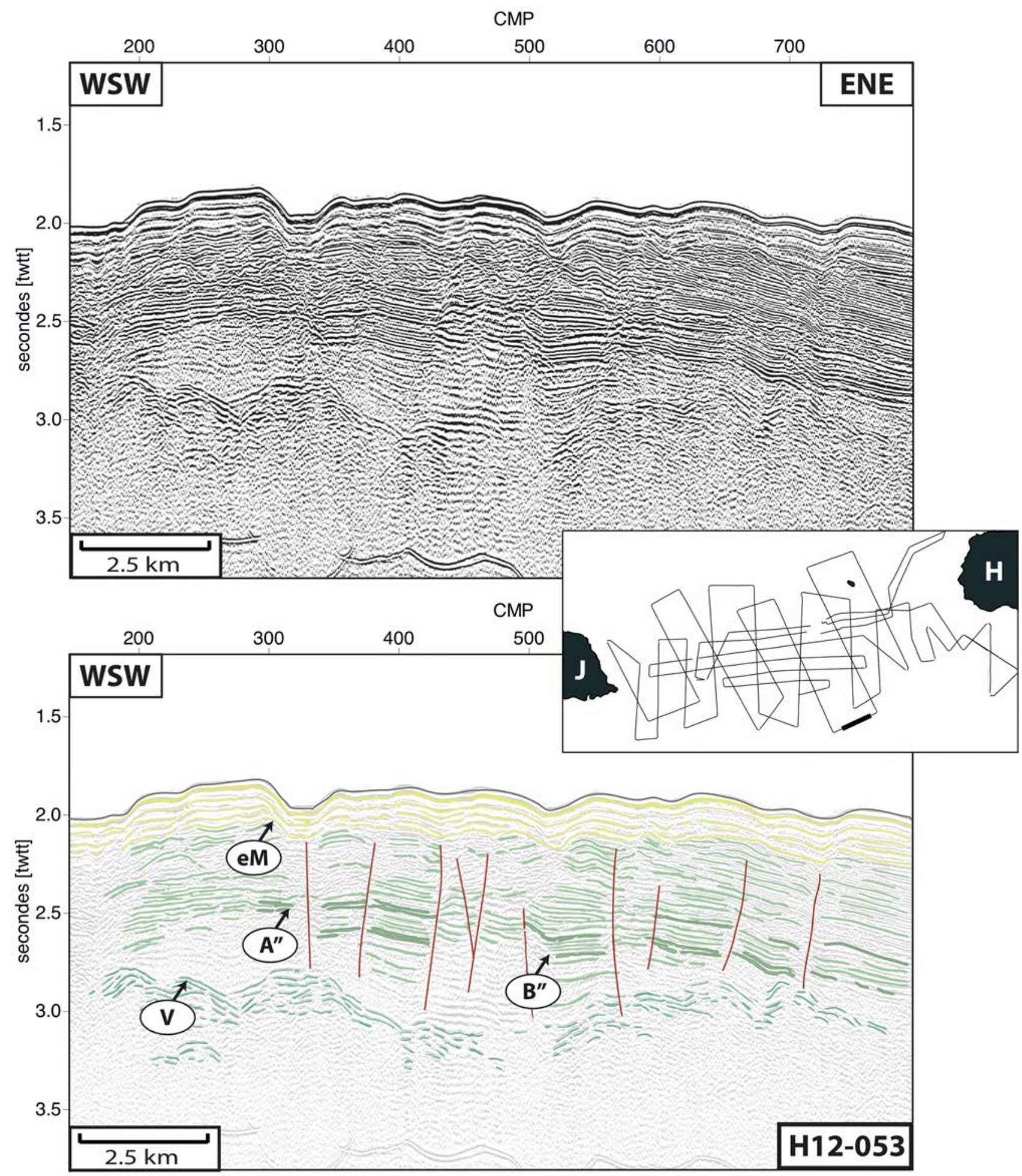

Figure 15: Detail of seismic profile H12-053 (upper panel) and proposed interpretation (lower panel). The different units identified are CLIP-type (Caribbean Large Igneous Province): eM, A", B" and V. See inset and Fig. 5 for location. 


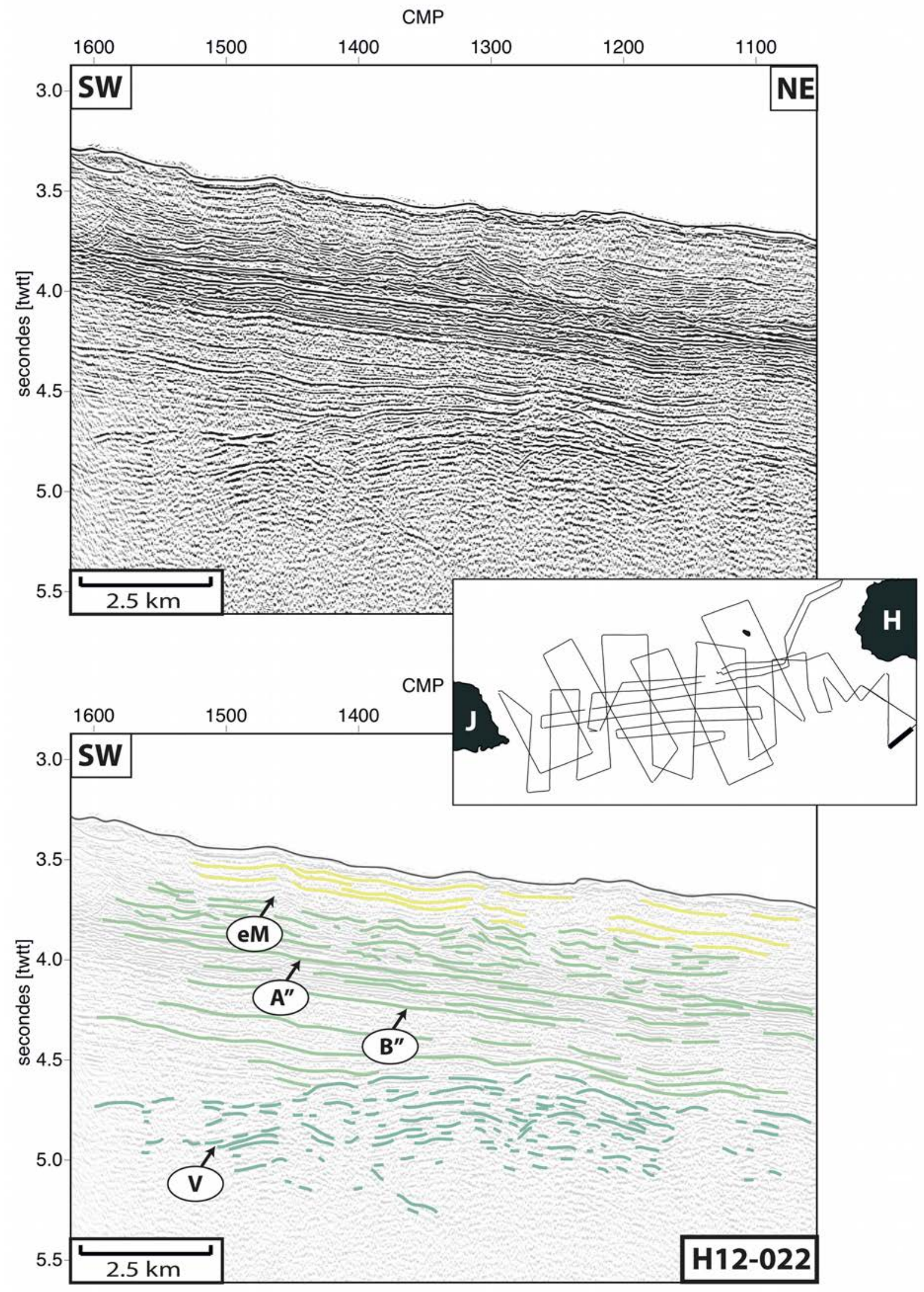


Figure 16: Detail of seismic profile H12-022 (upper panel) and a possible interpretation (lower panel). See inset and Fig. 5 for location.

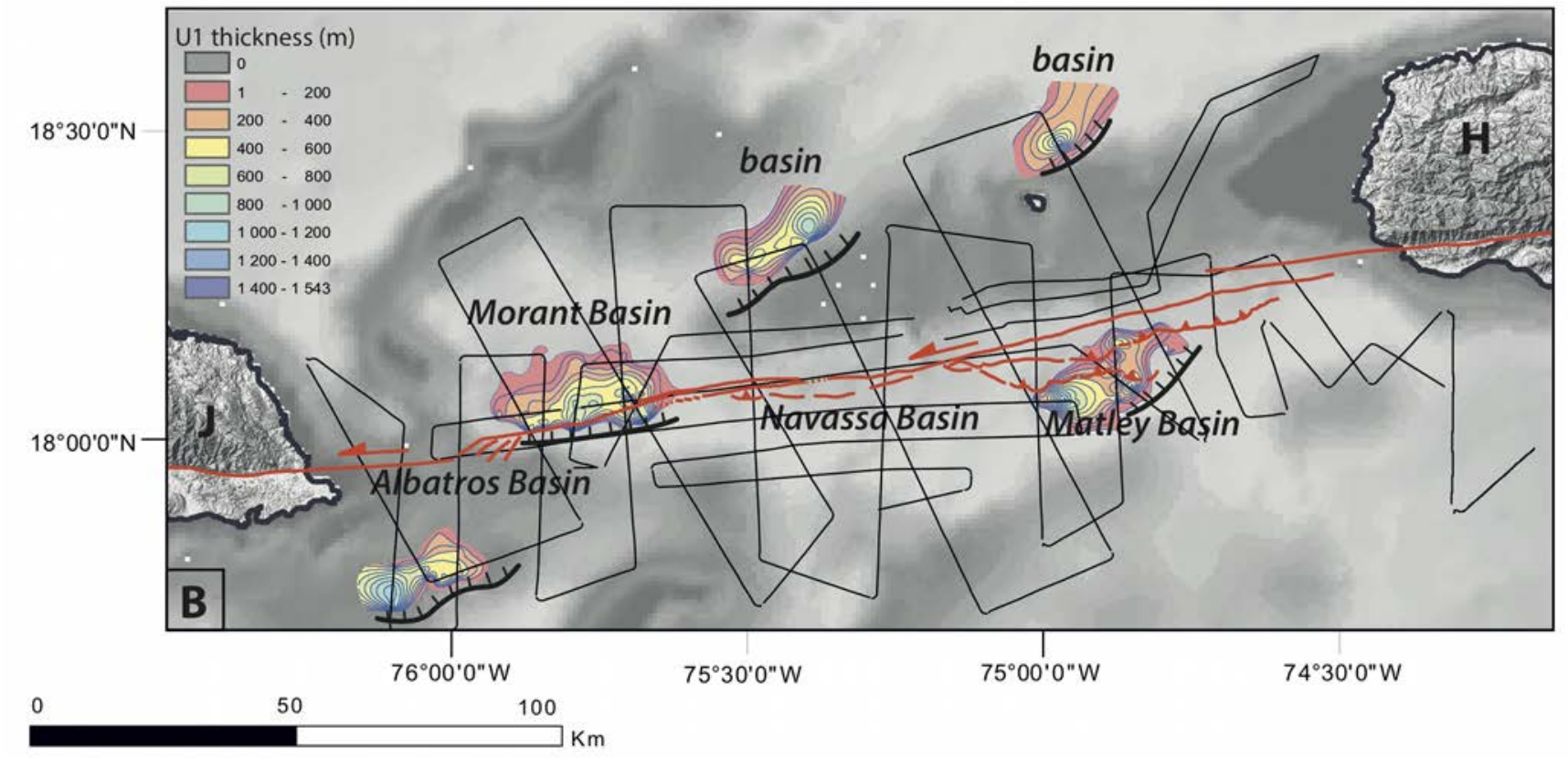

Figure 17: Isopach map of the U1 unit (syn-rift). The color scale indicates the depths in meters that are interpolated from the dense seismic coverage. Thicknesses are calculated with a velocity of $1500 \mathrm{~m} / \mathrm{s}$ for the water layer and $2200 \mathrm{~m} / \mathrm{s}$ for the interval U4-U2. The contour interval is $100 \mathrm{~m}$. The normal faults identified in the seismic profiles are indicated in black, and the present-day trace of the EPGFZ is indicated in red. The thin lines represent the tracklines of the seismic profiles. J: Jamaica; H: Hispaniola. The background is the shaded bathymetry where no U1 unit is identified. 


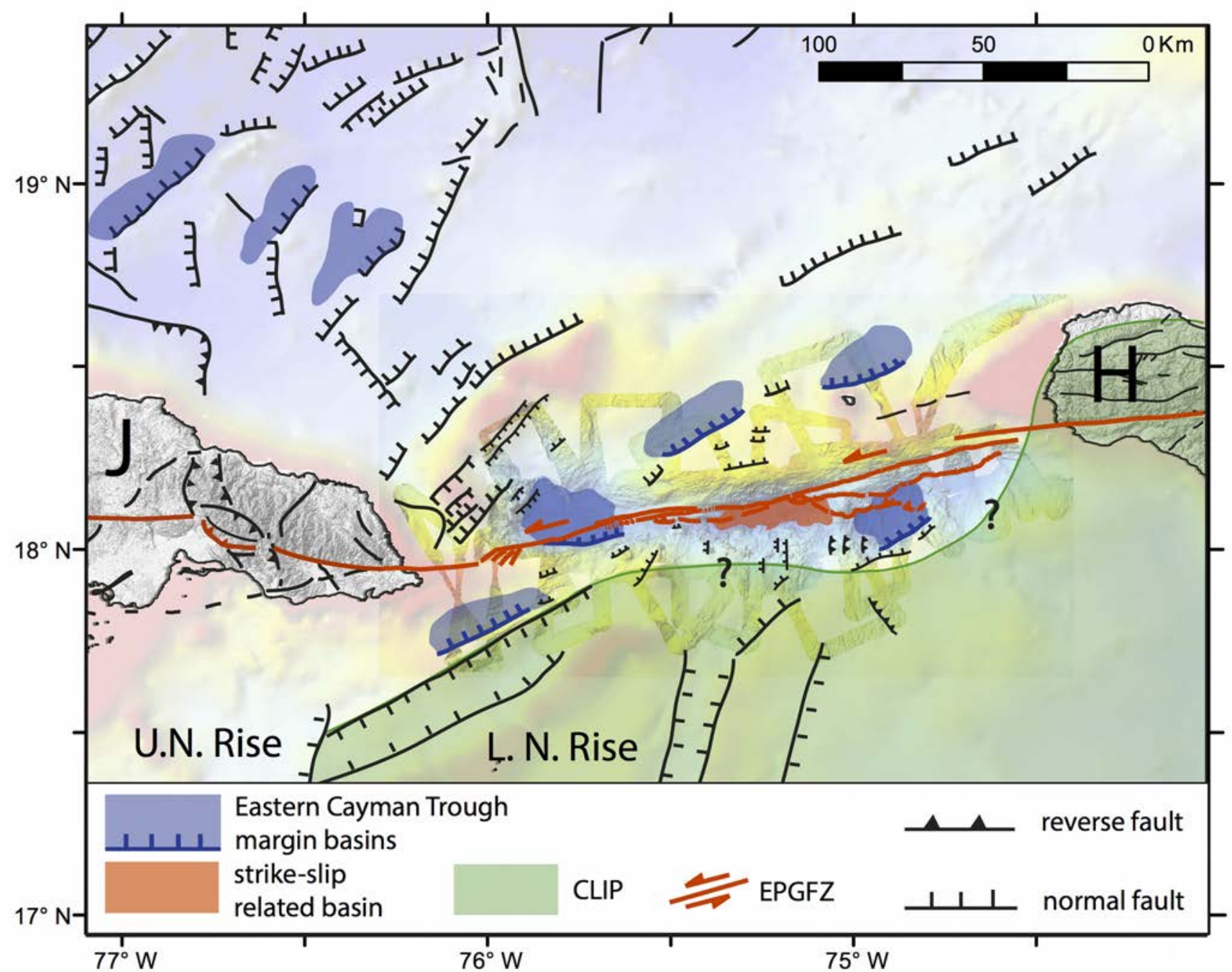

Figure 18: Structural sketch map of the Jamaica Passage showing our interpretation. J: Jamaica; H: Hispaniola. U. N. Rise: Upper Nicaraguan Rise, L. N. Rise: Lower Nicaraguan Rise. EPGFZ: Enriquillo-Plantain-Garden Fault Zone, CLIP: Caribbean Large Igneous Province. 